\title{
Organellar Calcium Handling in the Cellular Reticular Network
}

\author{
Wen-An Wang, ${ }^{1,3}$ Luis B. Agellon, ${ }^{2}$ and Marek Michalak ${ }^{1}$ \\ ${ }^{1}$ Department of Biochemistry, University of Alberta, Edmonton, Alberta T6G 2S7, Canada \\ ${ }^{2}$ School of Human Nutrition, McGill University, Ste. Anne de Bellevue, Quebec H9X 3V9, Canada \\ Correspondence: luis.agellon@mcgill.ca; marek.michalak@ualberta.ca
}

\begin{abstract}
$\mathrm{Ca}^{2+}$ is an important intracellular messenger affecting diverse cellular processes. In eukaryotic cells, $\mathrm{Ca}^{2+}$ is handled by a myriad of $\mathrm{Ca}^{2+}$-binding proteins found in organelles that are organized into the cellular reticular network (CRN). The network is comprised of the endoplasmic reticulum, Golgi apparatus, lysosomes, membranous components of the endocytic and exocytic pathways, peroxisomes, and the nuclear envelope. Membrane contact sites between the different components of the CRN enable the rapid movement of $\mathrm{Ca}^{2+}$, and communication of $\mathrm{Ca}^{2+}$ status, within the network. $\mathrm{Ca}^{2+}$-handling proteins that reside in the $\mathrm{CRN}$ facilitate $\mathrm{Ca}^{2+}$ sensing, buffering, and cellular signaling to coordinate the many processes that operate within the cell.
\end{abstract}

\section{INTRACELLULAR $\mathrm{Ca}^{2+}$ DYNAMICS AND THE CELLULAR RETICULAR NETWORK}

$\mathrm{C}^{2+}$ is a universal signaling ion involved in the regulation of numerous processes throughout the lifetime of the cell and the organism (Krebs et al. 2015; Berridge 2016). Inside the cell, the resting free $\mathrm{Ca}^{2+}$ concentration and $\mathrm{Ca}^{2+}$-signaling pathways must be tightly regulated because of the integral role of $\mathrm{Ca}^{2+}$ in nearly all aspects of cell physiology (Baumann and Walz 2001; Groenendyk et al. 2013; Krebs et al. 2015; Nunes-Hasler and Demaurex 2017; Prudent and McBride 2017). Cytoplasmic $\mathrm{Ca}^{2+}$ is maintained at a resting concentration that is two to three orders of magnitude lower than the extracellular free $\mathrm{Ca}^{2+}$ concentration (Krebs et al.
2015; Berridge 2016). This markedly lower cytoplasmic free $\mathrm{Ca}^{2+}$ concentration is maintained by action of $\mathrm{Ca}^{2+}$-handling proteins and the reticular network of intracellular membrane systems (Fig. 1) that comprise the endoplasmic reticulum (ER), sarcoplasmic reticulum (SR), Golgi apparatus, lysosomes, membranous components of the endocytic pathway, peroxisomes, and nuclear envelope (Prins and Michalak 2011; Krebs et al. 2015; Berridge 2016). This intracellular network of specialized membrane systems, the cellular reticular network (CRN), is linked together to facilitate and coordinate cellular function. The organelles of the CRN accumulate and store $\mathrm{Ca}^{2+}$ and maintain the $\mathrm{Ca}^{2+}$ stores at a higher concentration (mM) than that of cytoplasmic $\mathrm{Ca}^{2+}$. The ER is the dominating com-

\footnotetext{
${ }^{3}$ Present address: Department of Cellular Physiology and Metabolism, Faculty of Medicine, University of Geneva, CH-1211 Geneve 4, Switzerland.

Editors: Geert Bultynck, Martin D. Bootman, Michael J. Berridge, and Grace E. Stutzmann

Additional Perspectives on Calcium Signaling available at www.cshperspectives.org

Copyright (C) 2019 Cold Spring Harbor Laboratory Press; all rights reserved; doi: 10.1101/cshperspect.a038265

Cite this article as Cold Spring Harb Perspect Biol 2019;11:a038265
} 
W.-A. Wang et al.

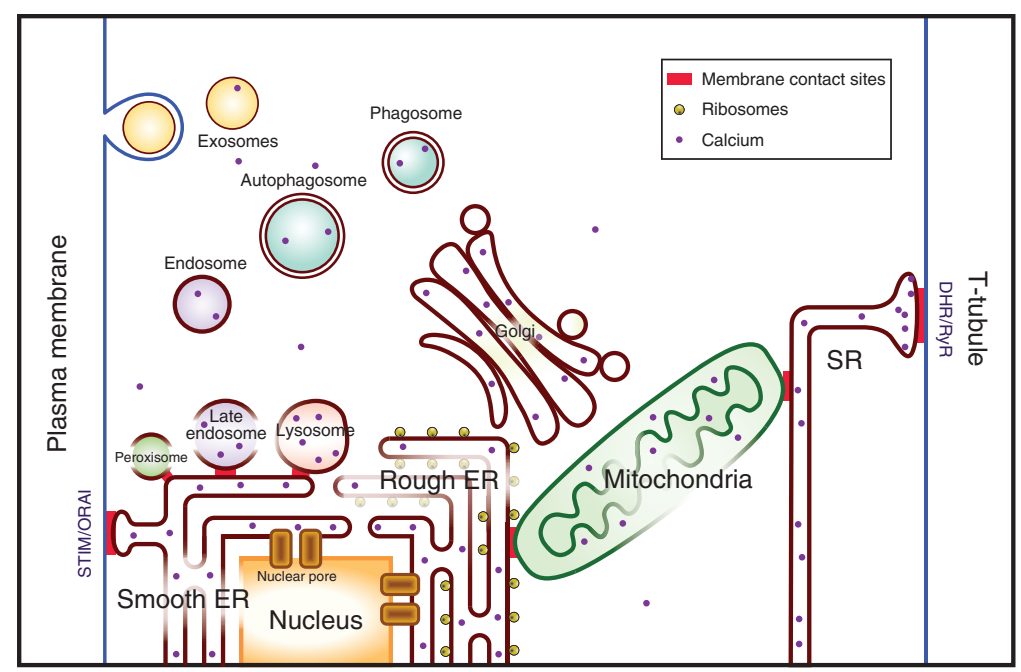

Figure 1. The cellular reticular network. Intracellular organelles are organized into the cellular reticular network that is linked by membrane contact sites ([MCSs], in red) allowing for rapid exchange of molecules between component of the network. DHR, Plasma membrane dihydropyridine $\mathrm{Ca}^{2+}$ channel receptor; RyR, ryanodine receptor/Ca ${ }^{2+}$ channel; InsP ${ }_{3} \mathrm{R}$, inositol 1,4,5-trisphosphate receptor; STIM, ER Ca ${ }^{2+}$ sensor; ORAI, plasma membrane $\mathrm{Ca}^{2+}$ channel; ER, endoplasmic reticulum.

ponent of the $\mathrm{CRN}$ and is the major $\mathrm{Ca}^{2+}$ store of the cell. Importantly, $\mathrm{Ca}^{2+}$ movement between components of the CRN plays an important role in regulation of cellular functions such as gene transcription (Zhang et al. 2009), cellular stresscoping strategies (Groenendyk et al. 2013; Dicks et al. 2015; Jung et al. 2017), and mitochondrial oxidative metabolism (Griffiths and Rutter 2009; De Stefani et al. 2016). This is achieved, at least in part, through membrane contact sites (MCSs) (Fig. 1), which are formed between closely apposed organellar membranes including the plasma membrane (Prinz 2014; Filadi and Pozzan 2015; Penny et al. 2015; Phillips and Voeltz 2016; Agellon and Michalak 2017; Barneda and Christian 2017; Joshi et al. 2017; Nunes-Hasler and Demaurex 2017; Prudent and McBride 2017). The organelles that make up the CRN contain specialized proteins responsible for the sensing, transport, and storage of intracellular $\mathrm{Ca}^{2+}$, and in orchestrating $\mathrm{Ca}^{2+}$ dynamics within the lumen of the network that are necessary to exert this cation's regulatory role (Corbett and Michalak 2000). For example, ER luminal $\mathrm{Ca}^{2+}$ dictates many functions of the ER, including protein synthesis and modifica- tion, protein folding and quality control, activation of unfolded protein responses (UPRs), interchaperone interactions, lipid synthesis, and cholesterol metabolism (Sambrook 1990; Corbett et al. 2000; Groenendyk et al. 2013; Wang et al. 2017).

\section{ENDOPLASMIC RETICULUM}

The ER is a major component of the CRN and a main $\mathrm{Ca}^{2+}$ storage organelle with a tightly regulated total (i.e., free and bound $\mathrm{Ca}^{2+}$ ) intraluminal $\mathrm{Ca}^{2+}$ concentration in excess of $2 \mathrm{~mm}$. The free $\mathrm{Ca}^{2+}$ concentration in the lumen of ER is maintained at the 10-500 $\mu \mathrm{M}$ range (Corbett and Michalak 2000; Yu and Hinkle 2000; Solovyova et al. 2002). $\mathrm{Ca}^{2+}$ is released from the ER via the inositol 1,4,5-trisphosphate receptor/ $\mathrm{Ca}^{2+}$ channel (InsP $\mathrm{P}_{3} \mathrm{R}$ ) or ryanodine receptor/ $\mathrm{Ca}^{2+}$ channel (RyR) (Krebs et al. 2015; Berridge 2016). The resulting increase in cytoplasmic $\mathrm{Ca}^{2+}$ level regulates many cellular processes, including cell proliferation, metabolism, and apoptosis (Berridge et al. 2000). The depletion of $\mathrm{ER} \mathrm{Ca}^{2+}$ triggers $\mathrm{Ca}^{2+}$ entry from the extracellular space via store-operated $\mathrm{Ca}^{2+}$ entry 
(SOCE), which further sustains cytoplasmic $\mathrm{Ca}^{2+}$ signal and, most importantly, supplies $\mathrm{Ca}^{2+}$ for refilling of the ER Ca ${ }^{2+}$ store (Berridge et al. 2000; Roos et al. 2005). Stromal interaction molecule 1 (STIM1) is an ER membrane type I transmembrane protein that acts as an $\mathrm{ER} \mathrm{Ca}^{2+}$ sensor (Liou et al. 2005; Roos et al. 2005; Zhang et al. 2005). The EF-hand of STIM1 binds $\mathrm{Ca}^{2+}$ $\left(K_{\mathrm{d}}=\sim 0.2-0.6 \mathrm{mM}\right)$ within the lumen of the ER (Stathopulos et al. 2006; Zheng et al. 2008) and on ER $\mathrm{Ca}^{2+}$ depletion, STIM1 extends its conformation, clusters, moves toward the plasma membrane, and binds to the cytosolic domain of Orail, a plasma membrane $\mathrm{Ca}^{2+}$ channel, to form MCS between the ER and the plasma membrane (Feske et al. 2006; Peinelt et al. 2006; Stathopulos et al. 2006; Muik et al. 2008; Park et al. 2009; Bhardwaj et al. 2016; Phillips and Voeltz 2016; Nwokonko et al. 2017). The interaction between STIM1 and Orail at the MCS causes oligomerization of Orail $\mathrm{Ca}^{2+}$ channel and the consequence of influx of $\mathrm{Ca}^{2+}$ (Peinelt et al. 2006; Prakriya et al. 2006; Mignen et al. 2008; Penna et al. 2008; Hou et al. 2012). The sarco-ER $\mathrm{Ca}^{2+}$ ATPase (SERCA) pumps $\mathrm{Ca}^{2+}$ from the cytosol into the ER to refill $\mathrm{Ca}^{2+}$ stores (Krebs et al. 2015; Berridge 2016).

The ER also plays a central role in managing cellular stress via mobilization of ER stress-coping responses, such as the UPR. The UPR involves three unique ER transmembrane signaling proteins: the inositol-requiring 1 (IRE1), ER kinase dsRNA-activated protein kinase-like ER kinase (PERK), and activating transcription factor 6 (ATF6) (Groenendyk et al. 2013; Wang and Kaufman 2016; Hetz and Papa 2018). Activation of ER stress-induced UPR signaling pathways result in translational attenuation and in transcriptional activation of genes encoding proteins involved in protein folding as well as genes for components of the ER-associated degradation pathway (Groenendyk et al. 2013; Wang and Kaufman 2016; Hetz and Papa 2018). Prolonged $\mathrm{ER} \mathrm{Ca}^{2+}$ depletion is a potent activator of UPR (Mekahli et al. 2011; Groenendyk et al. 2013). ER luminal $\mathrm{Ca}^{2+}$-binding proteins, notably BiP/GRP78 and PDIA6, regulate UPR signaling and illustrate the important link between ER $\mathrm{Ca}^{2+}$ homeostasis and ER stress responses
(Higo et al. 2010; Groenendyk et al. 2013 , 2014; Hetz and Papa 2018).

There are two categories of $\mathrm{Ca}^{2+}$-handling proteins as defined by their $\mathrm{Ca}^{2+}$-binding properties. The first binds $\mathrm{Ca}^{2+}$ with low affinity but high capacity. These proteins contribute to the $\mathrm{Ca}^{2+}$ storage and buffering capacity within organelles. The second binds $\mathrm{Ca}^{2+}$ with high affinity but low capacity. These proteins act as $\mathrm{Ca}^{2+}$ sensors as well as conveyors of $\mathrm{Ca}^{2+}$ dependent events into downstream components of intracellular signaling pathways (Krebs et al. 2015). Additionally, there are a variety of $\mathrm{Ca}^{2+}$-binding protein chaperones and folding enzymes localized within the lumen and membrane of the ER.

\section{Calreticulin}

Calreticulin is an ER luminal protein chaperone and a major $\mathrm{Ca}^{2+}$-binding protein that is important for maintaining $50 \%$ of the total $\mathrm{Ca}^{2+}$ within the ER $\mathrm{Ca}^{2+}$ (Gelebart et al. 2005). Calreticulin is 400 amino acid and $46 \mathrm{kDa}$ protein and is composed of three structural and functional domains. The highly conserved N-globular domain contains a disulfide-linkage and binding sites for polypeptides, carbohydrates, and $\mathrm{Zn}^{2+}$ (Baksh et al. 1995; Schrag et al. 2001; Leach et al. 2002; Kapoor et al. 2004). The $\mathrm{P}$-domain is the proline-rich extended arm of calreticulin that contains a binding site for the thiol oxidoreductase ERp57/PDIA3 and a highaffinity $\left(K_{\mathrm{d}}=1 \mu \mathrm{M}\right)$ but low-capacity ( $1 \mathrm{~mol}$ of $\mathrm{Ca}^{2+} / \mathrm{mol}$ of protein) $\mathrm{Ca}^{2+}$-binding site (Baksh and Michalak 1991; Tjoelker et al. 1994; Ellgaard et al. 2001, 2002; Frickel et al. 2002). Together, the $\mathrm{N}$ - and $\mathrm{P}$-domains comprise the protein chaperone unit of calreticulin (Nakamura et al 2001). The C-domain contains many acidic residues and is the $\mathrm{Ca}^{2+}$-binding unit of calreticulin, binding $\mathrm{Ca}^{2+}$ with low affinity $\left(K_{\mathrm{d}}=2 \mathrm{~mm}\right)$ but at high capacity $\left(20-30 \mathrm{~mol}\right.$ of $\mathrm{Ca}^{2+} / \mathrm{mol}$ of protein) (Tjoelker et al. 1994; Nakamura et al. 2001).

The role of calreticulin in maintaining ER homeostasis is illustrated in the effects of its loss- or gain-of-function on $\mathrm{ER} \mathrm{Ca}^{2+}$-signaling dynamics. Loss of calreticulin in mice is embry- 
W.-A. Wang et al.

onically lethal owing to inadequate $\mathrm{ER} \mathrm{Ca}^{2+}$ signaling. This is attributed to both the chaperone and $\mathrm{Ca}^{2+}$ storage function of calreticulin $(\mathrm{Me}-$ saeli et al. 1999). In the absence of calreticulin, ER $\mathrm{Ca}^{2+}$ stores, as measured by thapsigargininduced total $\mathrm{ER} \mathrm{Ca}^{2+}$ release, is reduced by 50\% (Nakamura et al. 2001). Furthermore, calreticulin-deficient cells were no longer responsive to bradykinin-induced $\mathrm{ER} \mathrm{Ca}^{2+}$ release, but permeabilized calreticulin-deficient cells remained responsive to $\mathrm{Ins}_{3}$-induced $\mathrm{ER} \mathrm{Ca} \mathrm{Ca}^{2+}$ release (Nakamura et al. 2001). The lack of response to bradykinin in calreticulin-deficient cells was caused by the absence of the chaperone function of calreticulin, which resulted in the misfolding of the plasma membrane bradykinin receptor and thus the loss of ability of cells to interact with bradykinin (Nakamura et al. 2001). This disrupted $\mathrm{Ca}^{2+}$ signaling from the ER caused by the absence of calreticulin led to insufficient activation of calcineurin and subsequent failure to stimulate transcription factors that induce the expression of responsive genes (Mesaeli et al. 1999; Guo et al. 2002; Lynch et al. 2005). In mice, calreticulin deficiency results in embryonic lethality owing to failure in cardiac development (Mesaeli et al. 1999). Remarkably, the lethality caused by calreticulin deficiency could be prevented by targeted expression of a constitutively active calcineurin solely in cardiac cells of mice with whole-body deficiency of calreticulin (Guo et al. 2002). On the other hand, overexpression of calreticulin increased total and free $\mathrm{ER} \mathrm{Ca}{ }^{2+}$ concentration (Bastianutto et al. 1995; Mery et al. 1996; Arnaudeau et al. 2002). This also led to a reduction in mitochondria $\mathrm{Ca}^{2+}$ causing mitochondrial damage and increasing cellular sensitivity to apoptosis (Arnaudeau et al. 2002). The increase in ER luminal $\mathrm{Ca}^{2+}$ concentration caused by calreticulin overexpression reduced STIM1 sensitivity to ER $\mathrm{Ca}^{2+}$, thereby decreasing and delaying SOCE activity (Mery et al. 1996).

The expected discovery of hyperlipidemia in calreticulin-deficient mice rescued from embryonic lethality by cardiac-specific expression of constitutively active calcineurin suggested a link between $\mathrm{Ca}^{2+}$ and lipid homeostasis (Guo et al. 2002). It is now evident that the decrease in ER luminal $\mathrm{Ca}^{2+}$ caused by the loss of calreticulin (Mesaeli et al. 1999; Nakamura et al. 2001) shifts the distribution of intracellular unesterified cholesterol, resulting in the depletion of the regulatory pool of cholesterol that controls cholesterol biosynthesis (Wang et al. 2017).

Immunoglobulin-Binding Protein/GlucoseRegulated Protein 78 (BiP/GRP78)

The molecular chaperone BiP/GRP78 binds hydrophobic regions of nascent proteins through the carboxy-terminal domain ( $C$ chain) and facilitates proper protein folding at the expense of ATP, as it is also an ATPase with an ATP/ ADP-binding site in the N-domain (A chain) (Gaut and Hendershot 1993; Awad et al. 2008). BiP/GRP78 is a key player in sensing ER stress through binding to accumulating misfolded proteins. However, it is also important for buffering $25 \%$ of total ER $\mathrm{Ca}^{2+}$ stores (Lievremont et al. 1997). The protein has four $\mathrm{Ca}^{2+}$ ionbinding acidic amino acid residues; two $\mathrm{Ca}^{2+}$ ions are accommodated in opposite chains by the coordination of His-252, Asp-257, and Gly-315; two other $\mathrm{Ca}^{2+}$ ions are held at the base of $\alpha$-helix- 6 by the hydroxyl group of His-252 and the carboxylate group of Glu-256 and Asp-257 (Wisniewska et al. 2010). Although BiP/GRP78 binds $\mathrm{Ca}^{2+}$ with low capacity (1-2 $\mathrm{mol} \mathrm{Ca}{ }^{2+} / \mathrm{mol}$ of protein), it contributes to $\mathrm{ER} \mathrm{Ca}^{2+}$ buffering owing to its high abundance in the lumen of the ER ( $\sim 5$-fold higher abundance than calreticulin) (Lievremont et al. 1997).

There is an intrinsic relationship between the chaperone and the $\mathrm{Ca}^{2+}$-binding functions of BiP/GRP78. Stoichiometrically, the binding affinity of BiP/GRP78 to $\mathrm{Ca}^{2+}$ changes in the presence of ATP or ADP. It binds $\mathrm{Ca}^{2+}$ with a $K_{\mathrm{d}}$ of $\sim 0.7 \mathrm{~mm}$ in the absence of ATP and ADP; a $K_{\mathrm{d}}$ of $\sim 18 \mu \mathrm{M}$ in the presence of ATP; and a $K_{\mathrm{d}}$ of $\sim 0.8 \mu \mathrm{M}$ in the presence of ADP (Lamb et al. 2006). The reverse is also true; in the presence of $\mathrm{Ca}^{2+}$, the binding affinity of ATP to BiP/GRP78 increases $\sim 11$-fold and the binding of ADP increases $\sim 930$-fold (Lamb et al. 2006). Functionally, the $\mathrm{ER} \mathrm{Ca}^{2+}$ level regulates the chaper- 
one activity of $\mathrm{BiP} / \mathrm{GRP} 78$ as reduction in ER $\mathrm{Ca}^{2+}$ levels causes dissociation of BiP/GRP78 from client proteins, and increases in $\mathrm{ER} \mathrm{Ca}^{2+}$ level inhibits BiP/GRP78-associated ATPase activity (Kassenbrock and Kelly 1989; Suzuki et al. 1991). This interconnected relationship between $\mathrm{ER} \mathrm{Ca}^{2+}$ store and signaling is a dynamic contributor to $\mathrm{Ca}^{2+}$ binding and chaperone activity of BiP/GRP78. Therefore, the abundance of BiP/GRP78 modulates ER-mitochondria $\mathrm{Ca}^{2+}$ flux and may play a protective role against mitochondria-induced apoptosis, depending on the level or duration of stress (Lievremont et al. 1997; Liu et al. 1997; Deniaud et al. 2008; Ouyang et al. 2011). Furthermore, BiP/ GRP78 is responsible for selectively gating and closing of ribosome-associated Sec61 translocon to prevent $\mathrm{Ca}^{2+}$ leakage at ER-mitochondria MCS and induction of apoptosis from ER stress (Haigh and Johnson 2002; Van Coppenolle et al. 2004; Alder et al. 2005; Schauble et al. 2012; Hammadi et al. 2013; Gutiérrez and Simmen 2018).

\section{Glucose-Regulated Protein}

The glucose-regulated protein (GRP94) is an ER protein chaperone that is involved in the folding and secretion of membrane proteins (Marzec et al. 2012). GRP94 is a heat shock protein 90 (HSP90)-like protein that contains an ATPbinding domain within the amino-terminal region, a client-binding region, and a dimerization domain within the carboxyl terminus (Marzec et al. 2012). In addition, GRP94 has a peptidebinding region in its amino-terminal region (Biswas et al. 2007). This major chaperone is involved in the folding of immunoglobulins (Melnick et al. 1994) and Toll-like receptors (Randow and Seed 2001). The peptide-binding activity of GRP94 is important for the immune response during $\mathrm{T}$-cell activation (Berwin et al. 2002; Li et al. 2005). GRP94 possesses four $\mathrm{Ca}^{2+}$-binding sites with high affinity $\left(K_{\mathrm{d}}=\right.$ $\sim 2 \mu \mathrm{M})$ and $11 \mathrm{Ca}^{2+}$-binding sites with low affinity $\left(K_{\mathrm{d}}=\sim 600 \mu \mathrm{M}\right)$ (Van et al. 1989), an EF-hand-like structure (Csermely et al. 1995), and is able to accommodate $16-28 \mathrm{~mol}$ of $\mathrm{Ca}^{2+} / \mathrm{mol}$ of protein (Macer and Koch 1988;
Van et al. 1989). In addition, the ER $\mathrm{Ca}^{2+}$ level affects the peptide-binding activity of GRP94; specifically, $\mathrm{Ca}^{2+}$ binding within the amino terminus (amino acids 266-355) induces a conformational change that favors peptide interaction (Van et al. 1989; Biswas et al. 2007).

The expression of GRP94 proteins is stimulated by induction of the UPR during ER stress, resulting from misfolding of proteins or perturbed ER $\mathrm{Ca}^{2+}$ homeostasis (Lee 1992). Depletion of GRP94 does not cause ER stress nor loss of ER $\mathrm{Ca}^{2+}$ homeostasis (Poirier et al. 2015); however, cells lacking GRP94 were more susceptible to thapsigargin-induced $\mathrm{ER} \mathrm{Ca}^{2+}$ depletion and cell death (Biswas et al. 2007). Expression of GRP94, similar to BiP/GRP78, showed antiapoptotic properties and protected cells from $\mathrm{Ca}^{2+}$ depletion-induced stress and apoptosis (Little and Lee 1995). Furthermore, the cleavage or degradation of GRP94 is mediated through the activity of $\mathrm{Ca}^{2+}$-dependent calpains during DNA damage-induced apoptosis (Reddy et al. 1999). Overexpression of GRP94 protected cardiomyocytes from intracellular $\mathrm{Ca}^{2+}$ overload and ischemia (Bando et al. 2003; Vitadello et al. 2003).

\section{Protein Disulfide Isomerase}

The protein disulfide isomerase (PDI) family of proteins were discovered in 1963 as ER proteins involved in co- and posttranslational modification of nascent synthesized proteins. Specifically, these proteins are important in the formation and cleavage of disulfide bonds (Goldberger et al. 1963), which is necessary for the proper folding of cysteine-containing proteins (Creighton et al. 1980). Subsequently, PDIs were identified as calsequestrin-like proteins of the ER (Oberdorf et al. 1988) and later glycoproteins with $\mathrm{Ca}^{2+}$-binding properties (Lebeche and Kaminer 1992). Mammalian PDIs have been shown to bind $\mathrm{Ca}^{2+}$ at high capacity (averaging at $19 \mathrm{~mol}$ of $\mathrm{Ca}^{2+} / \mathrm{mol}$ of protein) but with low affinity $\left(K_{\mathrm{d}}=4.7 \mathrm{~mm}\right)$ (Lebeche et al. 1994). The $\mathrm{Ca}^{2+}$-binding region of PDIs consists of a number of paired acidic residues within the carboxyl terminus of the protein (Freedman et al. 1994; Lucero et al. 1998). As PDIs contribute to the 
W.-A. Wang et al.

$\mathrm{Ca}^{2+}$ store within the ER, the level of $\mathrm{Ca}^{2+}$ in the ER (1-5 mM) in turn affects their overall enzymatic activity (Lucero and Kaminer 1999).

Recent reports indicate that PDI family of proteins influence ER stress responses and impact on the ER and cellular $\mathrm{Ca}^{2+}$ homeostasis. For example, PDIA6 plays a role in regulation of IRE $1 \alpha$ activity in response to $\mathrm{ER} \mathrm{Ca}^{2+}$ depletion (Groenendyk et al. 2014). PDIA3 (ERp57) interacts with, and regulates, STIM1 activity, thereby impacting on SOCE and cytoplasmic $\mathrm{Ca}^{2+}$ signaling (Prins et al. 2011), in addition to its key role in the quality control of newly synthesized glycoproteins (Coe and Michalak 2010). Furthermore, PDIA3 modulates the redox state of ER-facing thiols in SERCA2b in a $\mathrm{Ca}^{2+}$. dependent manner (Li and Camacho 2004) and PDIA10 (ERp44) modulates $\mathrm{Ca}^{2+}$ release by $\operatorname{InsP}_{3} \mathrm{R}$ (Higo et al. 2005).

\section{SARCOPLASMIC RETICULUM}

In some cells, the ER is further subspecialized into rough ER, such as in secretory cell types, and smooth ER, such as in cells that actively synthesize and metabolize lipids. In muscle cells, in addition to perinuclear rough and smooth ER, the ER is subspecialized into the SR (Fig. 1), which is responsible for the regulation of excitation-contraction-coupling to facilitate muscle contraction and relaxation (Bers 2014). The presence of highly specialized SR membrane networks in muscle cells supports mechanical functions requiring large fluxes of $\mathrm{Ca}^{2+}$, without compromising other important $\mathrm{Ca}^{2+}$-requiring cellular processes that are normally associated with ER (Michalak and Opas 2009). There are two well-defined structural and functional regions of the SR. The longitudinal SR, a membrane network around contractile myofibrils extending into the junctional SR, is a membrane network with multiple MCS with T-tubules formed from invaginations in the plasma membranes of muscle cells such as cardiomyocytes (Wray and Burdyga 2010; Bers 2014). The longitudinal SR is enriched with SERCA, and is responsible for rapid removal of $\mathrm{Ca}^{2+}$ from the cytoplasm to initiate muscle relaxation (Wray and Burdyga 2010; Bers 2014). The junction- al SR contains the RyR, responsible for $\mathrm{Ca}^{2+}$ release to the cytoplasm to initiate muscle contraction, and calsequestrin, a major $\mathrm{Ca}^{2+}$-binding protein of muscle (Rossi and Dirksen 2006; Wray and Burdyga 2010; Bers 2014). The SR luminal $\mathrm{Ca}^{2+}$-binding proteins calsequestrin, histidine-rich calcium-binding protein, junctate, and sarcalumenin are responsible for $\mathrm{Ca}^{2+}$ storage, whereas $\mathrm{RyR}$ is responsible for $\mathrm{Ca}^{2+}$ release to trigger muscle contraction.

\section{Calsequestrin}

Calsequestrin is the major $\mathrm{Ca}^{2+}$-binding protein within the SR, binding $\mathrm{Ca}^{2+}$ with high capacity (40-50 mol of $\mathrm{Ca}^{2+} / \mathrm{mol}$ of protein) but low affinity $\left(K_{\mathrm{d}}=\sim 1 \mathrm{~mm}\right)$ (MacLennan and Wong 1971). Two isoforms of calsequestrin exist and are encoded by two distinct genes: skeletal muscle calsequestrin (CASQ1) and cardiac calsequestrin (CASQ2) (Györke et al. 2009; Knollmann 2009). Structurally, calsequestrin is composed of three thioredoxin-like domains linked together to form a monomer with a hydrophilic core and a carboxyl terminus that contains the majority of paired acidic residues for $\mathrm{Ca}^{2+}$ binding (Wang et al. 1998). These $\mathrm{Ca}^{2+}$ binding sites have been termed the consecutive aspartate stretch at the carboxy-terminal domain (Kumar et al. 2013). The structure and oligomerization state of calsequestrin is dependent on the concentration of $\mathrm{Ca}^{2+}$ within the SR lumen (Ikemoto et al. 1974). Calsequestrin can dimerize and polymerize, and can exist as stable polymers at a $\mathrm{Ca}^{2+}$ concentration of $1 \mathrm{~mm}$ (the physiological stable level of $\mathrm{Ca}^{2+}$ within the SR lumen) (Franzini-Armstrong et al. 1987; Wang et al. 1998). The binding of calsequestrin monomers to $\mathrm{Ca}^{2+}$ mediates the oligomeric state of calsequestrin, as shown through crystallization studies (Sanchez et al. 2012). High $\mathrm{Ca}^{2+}$ concentration in the junctional SR supports calsequestrin polymerization (Wang et al. 1998; Beard et al. 2005), whereas $\mathrm{Ca}^{2+}$ depletion in the junctional SR causes calsequestrin depolymerization (Manno et al. 2017). The carboxyl terminus portion of calsequestrin contains a disordered region that is involved in the $\mathrm{Ca}^{2+}$-dependent polymerization properties of these proteins 
and accounts for the unique polymerization differences between calsequestrin 1 and 2 isoforms (Bal et al. 2015). These conformational changes are important for the role of calsequestrin in regulating $\mathrm{Ca}^{2+}$ storage and release.

Mice deficient in skeletal muscle calsequestrin (CASQ1) are viable but they show reduced $\mathrm{Ca}^{2+}$ release and $\mathrm{Ca}^{2+}$ transients (Paolini et al. 2007). Deficiency in cardiac calsequestrin (CASQ2) leads to an increased diastolic SR $\mathrm{Ca}^{2+}$ leak and development of catecholaminergic ventricular arrhythmias (Knollmann et al. 2006). Mutations in the CASQ2 gene cause a severe form of catecholaminergic polymorphic ventricular tachycardia (CPVT) (Faggioni et al. 2012).

\section{Histidine-Rich $\mathrm{Ca}^{2+}$-Binding Protein}

The histidine-rich $\mathrm{Ca}^{2+}$-binding protein (HRC) was first discovered in 1989 as a $165 \mathrm{kDa} \mathrm{Ca}^{2+}$. binding protein within the lumen of the SR (Campbell et al. 1983; Hofmann et al. 1989). HRC binds $\mathrm{Ca}^{2+}$ with high capacity (reported at $200 \mathrm{nmol}$ of $\mathrm{Ca}^{2+} / \mathrm{mg}$ of protein) but low affinity $\left(K_{\mathrm{d}}=1.9 \mathrm{~mm}\right)$ (Picello et al. 1992). Overexpression of HRC in rat cardiomyocytes (Fan et al. 2004) and rat neonatal cardiomyocytes increased SR $\mathrm{Ca}^{2+}$ store content and prevented SR $\mathrm{Ca}^{2+}$ depletion induced by cyclopiazonic acid (Kim et al. 2003).

HRC has also been found to be important for $\mathrm{Ca}^{2+}$ cycling within the SR lumen. The conformation of HRC, and its interaction with other proteins, are $\mathrm{Ca}^{2+}$-dependent. HRC can exist as a multimeric complex, which dissociates on $\mathrm{Ca}^{2+}$ binding (conditions of high $\mathrm{Ca}^{2+}$ concentration) caused by changes in conformation (Suk et al. 1999). Similar to calsequestrin, the HRC protein can bind to triadin, a junctional SR protein, through its carboxy-terminal region in a $\mathrm{Ca}^{2+}$. dependent fashion (Lee et al. 2001; Sacchetto et al. 2001). Furthermore, HRC forms a complex with SERCA and triadin to modulate $\mathrm{Ca}^{2+}$ uptake and release from the SR (Gregory et al. 2006; Arvanitis et al. 2007). Mice deficient for HRC showed increases in $\mathrm{Ca}^{2+}$ signaling, cardiomyocyte contractility, and rate of $\mathrm{SR} \mathrm{Ca}^{2+}$ uptake (Park et al. 2013). Therefore, HRC is integral to the maintenance of $\mathrm{Ca}^{2+}$ homeostasis within the SR.

\section{Junctate}

Junctate is a newly described protein that is expressed within the junctional SR. It is a $33-\mathrm{kDa}$ single-pass integral SR membrane protein with the amino-terminal portion facing the cytoplasm and the carboxy-terminal portion within the SR lumen, and acts as a high-capacity/lowaffinity $\mathrm{Ca}^{2+}$-binding protein (Treves et al. 2000). The carboxy-terminal luminal portion of junctate is enriched in negatively charged amino acid residues and the protein is able to bind $21 \mathrm{~mol}$ of $\mathrm{Ca}^{2+} / \mathrm{mol}$ of protein with an affinity of $K_{\mathrm{d}}=217 \mu \mathrm{M}$ (Treves et al. 2000). Junctate has a significant influence on $\mathrm{SR} \mathrm{Ca}^{2+}$ store capacity. Specifically, overexpression of junctate in mouse skeletal muscle increased both the $\mathrm{SR} \mathrm{Ca}^{2+}$ store content and $\mathrm{Ca}^{2+}$ release on induction (Divet et al. 2007). However, in cardiomyocytes isolated from transgenic mice, overexpression of junctate resulted in a reduced SR function and reduced abundance of SERCA and calsequestrin. This resulted in disrupted cardiac $\mathrm{Ca}^{2+}$ transients, inducing cardiac hypertrophy (Hong et al. 2008). On the other hand, the same investigators showed that overexpression of junctate in rat cardiomyocytes infected with junctate adenovirus system led to an increase in SERCA2a activity and $\mathrm{Ca}^{2+}$ uptake (Kwon and Kim 2009).

Additionally, junctate appears to play a major role in maintaining $\mathrm{Ca}^{2+}$ homeostasis in eukaryotic cells through the regulation of $\mathrm{Ca}^{2+}$ uptake/release and SOCE. Junctate was found to interact with SERCA2a, the cardiac SERCA isoform, in the SR of cardiomyocytes via its carboxy-terminal domain, and the luminal domain of SERCA2a (Kwon and Kim 2009). Junctate also regulates $\mathrm{Ca}^{2+}$ entry and stabilizes ER-plasma membrane junctions through complex interaction with $\mathrm{InsP}_{3} \mathrm{R}$ and transient receptor potential protein 3 (TRPC3) cation channels (Treves et al. 2004). Moreover, studies have implicated junctate as a component of the STIM1 and Orail complex that mediates SOCE (Srikanth et al. 2012; Guido et al. 2015). This 
W.-A. Wang et al.

interaction was shown to be important in $\mathrm{Ca}^{2+}$ signaling within immune cells, specifically affecting $\mathrm{Ca}^{2+}$ dynamics at both ER-plasma membrane junctions (Srikanth et al. 2012) and ER-phagosome junctions (Guido et al. 2015).

\section{Sarcalumenin}

Sarcalumenin was discovered as the $160-\mathrm{kDa}$ protein variant generated by alternative splicing of a messenger RNA (mRNA) transcript of a gene that encodes a $53-\mathrm{kDa}$ SR glycoprotein (Leberer et al. 1989). The protein binds $\mathrm{Ca}^{2+}$ at high capacity (30-35 mol of $\mathrm{Ca}^{2+} / \mathrm{mol}$ of protein) but with low affinity $\left(K_{\mathrm{d}}=300 \mu \mathrm{M}\right)$ (Leberer et al. 1990). The skeletal muscle of sarcalumenin-deficient mice showed delayed relaxation phase following contraction and reduced $\mathrm{Ca}^{2+}$ uptake into the SR (Yoshida et al. 2005). Similarly, the cardiac performance of sarcalumenin-deficient mice was impaired. Further analysis of sarcalumenin-deficient cardiomyocytes revealed slow contraction and relaxation along with disrupted $\mathrm{Ca}^{2+}$ signaling (Yoshida et al. 2005). These mice, however, showed an increase in SOCE and a resistance to muscle fatigue in response to treadmill exercise (Zhao et al. 2005). Furthermore, sarcalumenin-deficient mice displayed reduced cardiac function in the presence of biomechanical stress. This was attributed to the absence of sarcalumenin function in regulating $\mathrm{SR} \mathrm{Ca}^{2+}$ handling through its interaction with SERCA (Shimura et al. 2008; Jiao et al. 2009, 2012).

\section{MITOCHONDRIA}

Mitochondrial $\mathrm{Ca}^{2+}$ uptake and accumulation are important components of cellular $\mathrm{Ca}^{2+}$ homeostasis and signaling. This process does not depend on any mitochondrial $\mathrm{Ca}^{2+}$-buffering proteins, but rather on the membrane potential difference resulting from the electrochemical gradient generated by the $\mathrm{H}^{+}$ions pumped into the intermembrane space by the electron transport chain. This membrane potential drives $\mathrm{Ca}^{2+}$ from the cytoplasm through the outer and inner mitochondrial membranes. The outer mitochondrial membrane is ion permeable owing to the presence of large-conductance voltage-dependent anion channels, which are also permeable to $\mathrm{Ca}^{2+}$ ions (Rapizzi et al. 2002). $\mathrm{Ca}^{2+}$ transport across the ion impermeable inner mitochondrial membrane occurs through the mitochondrial $\mathrm{Ca}^{2+}$ uniporter complex (Kirichok et al. 2004), which allows rapid accumulation of $\mathrm{Ca}^{2+}$ into the mitochondrial matrix at a $V_{\max }>1400 \mathrm{nmol}$ of $\mathrm{Ca}^{2+} / \mathrm{mg}$ of protein/min (Bragadin et al. 1979). Mitochondrial $\mathrm{Ca}^{2+}$ uptake occurs at ER-mitochondria MCS in proximity to ER membrane $\mathrm{Ca}^{2+}$ channels such as the Ins $\mathrm{P}_{3} \mathrm{R}$ and the RyR, and depends on the high $\mathrm{Ca}^{2+}$ concentration hotspots at these microdomains (Rizzuto et al. 1993, 1998; Szalai et al. 2000).

In this sense, the generation of mitochondrial $\mathrm{Ca}^{2+}$ hotspots (Csordas et al. 2010; Giacomello et al. 2010), together with the rapid and large accumulation of $\mathrm{Ca}^{2+}$ within mitochondria on stimulation, suggests a role for mitochondria as a $\mathrm{Ca}^{2+}$-buffer within the cell. This might also enable modulation of $\mathrm{Ca}^{2+}$ levels and thus $\mathrm{Ca}^{2+}$ signaling in the immediate proximity of mitochondria. The $\operatorname{Ins}_{3} \mathrm{R}$ activity is regulated by cytoplasmic $\mathrm{Ca}^{2+}$ concentrations (Bezprozvanny et al. 1991) and mitochondrial uptake or sequestering of $\mathrm{Ca}^{2+}$ during ER $\mathrm{Ca}^{2+}$ release suppresses $\mathrm{Ca}^{2+}$ feedback activation of $\mathrm{InsP}_{3} \mathrm{R}$ (Hajnoczky et al. 1999). Moreover, $\mathrm{Ca}^{2+}$ uptake by mitochondria can occur near Orai $\mathrm{Ca}^{2+}$ channels on the plasma membrane and thus modulate channel activity during SOCE (Hoth et al. 1997; Gilabert and Parekh 2000). Furthermore, $\mathrm{Ca}^{2+}$ uptake by mitochondria stimulates the tricarboxylic acid (TCA) cycle and oxidative phosphorylation and prevents induction of autophagy (Cardenas et al. 2016; Singh et al. 2017; Bootman et al. 2018; Morciano et al. 2018).

\section{GOLGI APPARATUS}

The Golgi apparatus accounts for up to $5 \%$ of the total cellular $\mathrm{Ca}^{2+}$ store (Chandra et al. 1991). The Golgi $\mathrm{Ca}^{2+}$ store is important for the optimal function of certain enzymes within the organelle (Oda 1992; Carnell and Moore 1994), retrograde transport (Ivessa et al. 1995; 
Micaroni et al. 2010), and secretory protein sorting (Chanat and Huttner 1991; Micaroni et al. 2010). The Golgi $\mathrm{Ca}^{2+}$ store is sensitive to $\mathrm{InsP}_{3}$ production as there are Ins $\mathrm{P}_{3} \mathrm{R}$ in Golgi structures (Pinton et al. 1998). However, the $\mathrm{Ca}^{2+}$ released from Ins $\mathrm{P}_{3} \mathrm{R}$ on Golgi membranes is functionally distinct from that originating from ER $\mathrm{Ca}^{2+}$ stores (Vanoevelen et al. 2004). The Golgi $\mathrm{Ca}^{2+}$ store is maintained via the activity of SERCA and the secretory pathway $\mathrm{Ca}^{2+}$ ATPase1 (SPCA1), which is able to pump $\mathrm{Ca}^{2+}$ from the cytoplasm into the Golgi (Wuytack et al. 2003; Micaroni et al. 2010; Vandecaetsbeek et al. 2011). Although $\mathrm{Ca}^{2+}$ is present within the lumen of the entire Golgi network (Pezzati et al. 1997), the handling of $\mathrm{Ca}^{2+}$ across the Golgi network is heterogeneous (Wong et al. 2013; Aulestia et al. 2015). There is a $\mathrm{Ca}^{2+}$ gradient within the Golgi apparatus whereby the $\mathrm{Ca}^{2+}$ concentration within the lumen of the Golgi is higher than that of trans-Golgi (but lower than that of the ER) (Wong et al. 2013). Furthermore, the cis-Golgi accumulates $\mathrm{Ca}^{2+}$ mostly from SERCA activity, whereas the trans-Golgi accumulates $\mathrm{Ca}^{2+}$ through the action of SPCA1 (Aulestia et al. 2015). In addition, $\mathrm{Ca}^{2+}$ release via Ins $\mathrm{P}_{3} \mathrm{R}$ occurs only from the cis- and the second trans-Golgi portion, whereas $\mathrm{Ca}^{2+}$ release from all of Golgi can be induced by caffeine (Aulestia et al. 2015). The heterogeneity of $\mathrm{Ca}^{2+}$ concentration in the Golgi may reflect differing regulatory functions for $\mathrm{Ca}^{2+}$ within the different Golgi compartments.

\section{CALNUC}

CALNUC is a major $\mathrm{Ca}^{2+}$-binding protein within the Golgi apparatus and is highly homologous to calreticulin (Lin et al. 1998). Structurally, it consists of a signal peptide, followed by a basic amino acid region, an acidic amino acid region that makes up two EF-hand motifs (de Alba and Tjandra 2004), and a leucine zipper motif (Miura et al. 1992; Lin et al. 1998). CALNUC binds $\mathrm{Ca}^{2+}$ with high affinity $\left(K_{\mathrm{d}}=6.6 \mu \mathrm{M}\right)$ but at low capacity (1.1 mol of $\mathrm{Ca}^{2+} / \mathrm{mol}$ of protein) (Lin et al. 1999), and accounts for the majority of Golgi $\mathrm{Ca}^{2+}$ stores by virtue of its high abundance in this organelle ( $\sim 3.8 \mu \mathrm{g}$ of CALNUC/ mg of total Golgi protein) (Lin et al. 1999). CALNUC has been recently implicated in the endosome-to-trans-Golgi retrograde transport of lysosomal receptors the recruitment of retromers to endosomes (Larkin et al. 2016).

\section{Calumenin}

Calumenin is also a part of the CREC (acronym derived from the four main family members: Cab45, reticulocalbin1, ERC-55, and calumenin; Yabe et al. 1998) family of EF-hand-containing proteins and is localized to both the ER and the Golgi (Vorum et al. 1998). The protein contains an amino-terminal signal sequence, an HDEF ER retrieval signal, and seven EFhand motifs, each with low $\mathrm{Ca}^{2+}$-affinity $\left(K_{\mathrm{d}}=\right.$ $1.6 \mathrm{~mm}$ ) (Vorum et al. 1998). Calumenin can be further processed and secreted by cultured cells (Vorum et al. 1999). Furthermore, it is highly expressed within the brain during development and may play a role in neuronal $\mathrm{Ca}^{2+}$-signaling (Vasiljevic et al. 2012).

Cab45 was the first $\mathrm{Ca}^{2+}$-binding luminalresident protein of the Golgi apparatus to be discovered, and is a $45-\mathrm{kDa}$ protein belonging to the superfamily of CREC proteins (Scherer et al. 1996; Honore and Vorum 2000). Cab45 is a soluble protein and contains an amino-terminal signal sequence and six EF-hand motifs (Scherer et al. 1996). The function of Cab45 includes sorting of secretory proteins within the trans-Golgi and occurs in a SPCA-1- and $\mathrm{Ca}^{2+}$-dependent manner (von Blume et al. 2012). The binding of $\mathrm{Ca}^{2+}$ evokes an oligomerized state that enables Cab45 activity (Crevenna et al. 2016). Oligomerized Cab45 binds a variety of proteins destined for cellular secretion. Cab45 plays an important $\mathrm{Ca}^{2+}$-dependent role in sorting cargo export at the trans-Golgi membrane through its association with SPCA-1 and actin (Blank and von Blume 2017).

\section{p54/NEFA}

The DNA-binding, EF-hand, acidic region ( $\mathrm{p} 54 / \mathrm{NEFA})$ protein contains a basic region, two EF-hand motifs and a leucine zipper repeat (Karabinos et al. 1996). p54/NEFA is a resident 
W.-A. Wang et al.

of medial Golgi and is retained within the ER through its amino-terminal Leu/Ile rich region (Nesselhut et al. 2001; Morel-Huaux et al. 2002).

\section{ENDOSOME/LYSOSOME/PEROXISOME/ PHAGOSOME}

Endosomes and lysosomes have emerging roles in $\mathrm{Ca}^{2+}$ storage and signaling. As endosomes mature into late endosomes and subsequently fuse with lysosomes, the gradual acidification of the vesicles is accompanied by a concomitant increase in $\mathrm{Ca}^{2+}$ concentration (Gerasimenko et al. 1998; Pryor et al. 2000). The concentration of $\mathrm{Ca}^{2+}$ within the lumen of lysosomes is estimated to range from $400 \mu \mathrm{M}$ to $600 \mu \mathrm{M}$ (Christensen et al. 2002; Lloyd-Evans et al. 2008). $\mathrm{Ca}^{2+}$ release from the endosome/s/lysosomes shown to be sensitive to nicotinic acid adenine dinucleotide phosphate (NAADP) treatment is mediated by the RyR and TPC2 channels (Mojzisova et al. 2001; Hohenegger et al. 2002; Gerasimenko et al. 2003; Brailoiu et al. 2010; Lin-Moshier et al. 2014; Davis et al. 2015; Galione 2015; Hockey et al. 2015; Ruas et al. 2015) and is distinct from $\mathrm{Ca}^{2+}$ released from $\mathrm{InsP}_{3-}$ sensitive ER stores (Lee and Aarhus 1995; Genazzani and Galione 1996; Lopez-Sanjurjo et al. 2013). The transient receptor potential (TRPML) channels belonging to the mucolipin family and the two-pore channels are also involved in the release of $\mathrm{Ca}^{2+}$ from the acidic stores in these organelles (Patel and Muallem 2011; Kilpatrick et al. 2013, 2016; Penny et al. 2015; Atakpa et al. 2018).

Currently, the existence of endosomal/lysosomal $\mathrm{Ca}^{2+}$-buffering proteins are unknown. The uptake and accumulation of $\mathrm{Ca}^{2+}$ within these acidic stores seem to be highly dependent on pH (Christensen et al. 2002; Morgan et al. 2013). Uptake of $\mathrm{Ca}^{2+}$ into lysosomes occurs through the $\mathrm{H}^{+} / \mathrm{Ca}^{2+}$ exchanger, vacuolar (V)type $\mathrm{H}^{+}$-ATPase (Pryor et al. 2000), and $\mathrm{Ca}^{2+}$ / $\mathrm{H}^{+}$exchanger (CAX) (Melchionda et al. 2016). Furthermore, the $\mathrm{Ca}^{2+}$ storage and signaling capacity of the endosomal/lysosomal pathway is highly dependent on $\mathrm{Ca}^{2+}$ signaling and exchange with the ER at ER-endosomal/-lysosomal MCS (Penny et al. 2015; Ronco et al. 2015).
Movement of $\mathrm{Ca}^{2+}$ between the ER and the endosomal/lysosomal pathway is important for the progression, maturation, fusion events of the endosomes/lysosomes, and autophagy (Huotari and Helenius 2011; Coen et al. 2012; Bootman et al. 2018).

Peroxisomes are capable of storing $\mathrm{Ca}^{2+}$ within their lumen at concentrations higher than that in cytoplasm (Lasorsa et al. 2008; Costa et al. 2013). However, it is not known how $\mathrm{Ca}^{2+}$ is stored or buffered in this organelle. It is thought that $\mathrm{Ca}^{2+}$ is involved in the regulation of autophagy, a process that delivers proteins and damaged organelles to the lysosome for breakdown to promote cell survival under conditions of nutrient deprivation (Decuypere et al. 2011; Tong and Song 2015). The fate of $\mathrm{Ca}^{2+}$ trapped during phagosomal formation and how it is stored in phagosome is not known.

\section{SUMMARY}

It is evident that there is rich variety of $\mathrm{Ca}^{2+}$ handling proteins that bind the ion with differing affinities and capacities distributed throughout the cell, and especially within the organellar components that make up the CRN. $\mathrm{Ca}^{2+}$-handling proteins that bind $\mathrm{Ca}^{2+}$ with high affinity but low capacity likely function as sensors or conveyors of $\mathrm{Ca}^{2+}$-dependent signaling events, whereas those that bind $\mathrm{Ca}^{2+}$ with low affinity but high capacity are likely involved in storage or buffering of $\mathrm{Ca}^{2+}$ in the local milieu. The rapid movement of $\mathrm{Ca}^{2+}$ and communication of luminal $\mathrm{Ca}^{2+}$ status, among the different compartments of the CRN may be partly facilitated through MCS, which themselves are characterized by a unique set of accessory proteins, including specific $\mathrm{Ca}^{2+}$-handling proteins, depending on the membranes involved in the formation of the MCS. A recent study illustrated that luminal ER $\mathrm{Ca}^{2+}$ status has a dramatic impact on the intracellular distribution of unesterified cholesterol, and thus alters the set point of the basal-sensing mechanism responsible for cholesterol homeostasis. In the years to come, it will be interesting to uncover how the diverse collection of $\mathrm{Ca}^{2+}$-handling proteins within the cell are networked to coordinate the manifold 
and simultaneous cellular processes that enable the cell to exist and carry out its functions.

\section{ACKNOWLEDGMENTS}

Work in our laboratories is supported by the Canadian Institutes of Health Research (CIHR) Grants MOP-15291, MOP-15415, and PS-153325 to M.M.; a generous donation from the Kenneth and Sheelagh McCourt family; CIHR Grant MOP-15291 and PS-153325 to L.B.A. W.-A.W. was supported by a CIHR studentship.

\section{REFERENCES}

Agellon LB, Michalak M. 2017. The endoplasmic reticulum and the cellular reticular network. Adv Exp Med Biol 981: 61-76. doi:10.1007/978-3-319-55858-5_4

Alder NN, Shen Y, Brodsky JL, Hendershot LM, Johnson AE. 2005. The molecular mechanisms underlying BiPmediated gating of the Sec61 translocon of the endoplasmic reticulum. J Cell Biol 168: 389-399. doi:10.1083/jcb 200409174

Arnaudeau S, Frieden M, Nakamura K, Castelbou C, Michalak M, Demaurex N. 2002. Calreticulin differentially modulates calcium uptake and release in the endoplasmic reticulum and mitochondria. J Biol Chem 277: 4669646705. doi:10.1074/jbc.M202395200

Arvanitis DA, Vafiadaki E, Fan GC, Mitton BA, Gregory KN, Del Monte F, Kontrogianni-Konstantopoulos A, Sanoudou D, Kranias EG. 2007. Histidine-rich Ca-binding protein interacts with sarcoplasmic reticulum Ca-ATPase. Am J Physiol Heart Circ Physiol 293: H1581-H1589. doi:10.1152/ajpheart.00278.2007

Atakpa P, Thillaiappan NB, Mataragka S, Prole DL, Taylor CW. 2018. $\mathrm{IP}_{3}$ receptors preferentially associate with ER-lysosome contact sites and selectively deliver $\mathrm{Ca}^{2+}$ to lysosomes. Cell Rep 25: 3180-3193.e7. doi:10.1016/j .celrep.2018.11.064

Aulestia FJ, Alonso MT, Garcia-Sancho J. 2015. Differential calcium handling by the cis and trans regions of the Golgi apparatus. Biochem J 466: 455-465. doi:10.1042/ BJ20141358

Awad W, Estrada I, Shen Y, Hendershot LM. 2008. BiP mutants that are unable to interact with endoplasmic reticulum DnaJ proteins provide insights into interdomain interactions in BiP. Proc Natl Acad Sci 105: 1164-1169. doi:10.1073/pnas.0702132105

Baksh S, Michalak M. 1991. Expression of calreticulin in Escherichia coli and identification of its $\mathrm{Ca}^{2+}$ binding domains. J Biol Chem 266: 21458-21465.

Baksh S, Spamer C, Heilmann C, Michalak M. 1995. Identification of the $\mathrm{Zn}^{2+}$ binding region in calreticulin. FEBS Lett 376: 53-57. doi:10.1016/0014-5793(95)01246-4

Bal NC, Jena N, Chakravarty H, Kumar A, Chi M, Balaraju T, Rawale SV, Rawale JS, Sharon A, Periasamy M. 2015.
The C-terminal calcium-sensitive disordered motifs regulate isoform-specific polymerization characteristics of calsequestrin. Biopolymers 103: 15-22. doi:10.1002/bip .22534

Bando Y, Katayama T, Kasai K, Taniguchi M, Tamatani M, Tohyama M. 2003. GRP94 (94 kDa glucose-regulated protein) suppresses ischemic neuronal cell death against ischemia/reperfusion injury. Eur J Neurosci 18: 829-40. doi:10.1046/j.1460-9568.2003.02818.x

Barneda D, Christian M. 2017. Lipid droplet growth: Regulation of a dynamic organelle. Curr Opin Cell Biol 47: 9-15. doi:10.1016/j.ceb.2017.02.002

Bastianutto C, Clementi E, Codazzi F, Podini P, De Giorgi F, Rizzuto R, Meldolesi J, Pozzan T. 1995. Overexpression of calreticulin increases the $\mathrm{Ca}^{2+}$ capacity of rapidly exchanging $\mathrm{Ca}^{2+}$ stores and reveals aspects of their lumenal microenvironment and function. J Cell Biol 130: 847-855. doi:10.1083/jcb.130.4.847

Baumann O, Walz B. 2001. Endoplasmic reticulum of animal cells and its organization into structural and functional domains. Int Rev Cytol 205: 149-214. doi:10.1016/ S0074-7696(01)05004-5

Beard NA, Casarotto MG, Wei L, Varsányi M, Laver DR, Dulhunty AF. 2005. Regulation of ryanodine receptors by calsequestrin: Effect of high luminal $\mathrm{Ca}^{2+}$ and phosphorylation. Biophys J 88: 3444-3454. doi:10.1529/biophysj .104 .051441

Berridge MJ. 2016. The inositol trisphosphate/calcium signaling pathway in health and disease. Physiol Rev 96: 1261-1296. doi:10.1152/physrev.00006.2016

Berridge MJ, Lipp P, Bootman MD. 2000. The versatility and universality of calcium signalling. Nat Rev Mol Cell Biol 1: 11-21. doi:10.1038/35036035

Bers DM. 2014. Cardiac sarcoplasmic reticulum calcium leak: Basis and roles in cardiac dysfunction. Annu Rev Physiol 76: 107-127. doi:10.1146/annurev-physiol020911-153308

Berwin B, Rosser MF, Brinker KG, Nicchitta CV. 2002. Transfer of GRP94(Gp96)-associated peptides onto endosomal MHC class I molecules. Traffic 3: 358-366. doi:10.1034/j.1600-0854.2002.30505.x

Bezprozvanny I, Watras J, Ehrlich BE. 1991. Bell-shaped calcium-response curves of $\operatorname{Ins}(1,4,5) \mathrm{P}_{3^{-}}$and calciumgated channels from endoplasmic reticulum of cerebellum. Nature 351: 751-754. doi:10.1038/351751a0

Bhardwaj R, Hediger MA, Demaurex N. 2016. Redox modulation of STIM-ORAI signalling. Cell Calcium 60: 142152. doi:10.1016/j.ceca.2016.03.006

Biswas C, Ostrovsky O, Makarewich CA, Wanderling S, Gidalevitz T, Argon Y. 2007. The peptide-binding activity of GRP94 is regulated by calcium. Biochem J 405: 233241. doi:10.1042/BJ20061867

Blank B, von Blume J. 2017. Cab45-Unraveling key features of a novel secretory cargo sorter at the trans-Golgi network. Eur J Cell Biol 96: 383-390. doi:10.1016/j.ejcb.2017 .03 .001

Bootman MD, Chehab T, Bultynck G, Parys JB, Rietdorf K. 2018. The regulation of autophagy by calcium signals: Do we have a consensus? Cell Calcium 70: 32-46. doi:10 .1016/j.ceca.2017.08.005 
W.-A. Wang et al.

Bragadin M, Pozzan T, Azzone GF. 1979. Activation energies and enthalpies during $\mathrm{Ca}^{2+}$ transport in rat liver mitochondria. FEBS Lett 104: 347-351. doi:10.1016/00145793(79)80849-2

Brailoiu E, Rahman T, Churamani D, Prole DL, Brailoiu GC, Hooper R, Taylor CW, Patel S. 2010. An NAADP-gated two-pore channel targeted to the plasma membrane uncouples triggering from amplifying $\mathrm{Ca}^{2+}$ signals. $J$ Biol Chem 285: 38511-38516. doi:10.1074/jbc.M110.162073

Campbell KP, MacLennan DH, Jorgensen AO. 1983. Staining of the $\mathrm{Ca}^{2+}$-binding proteins, calsequestrin, calmodulin, troponin C, and S-100, with the cationic carbocyanine dye "Stains-all." J Biol Chem 258: 11267-11273.

Cardenas C, Muller M, McNeal A, Lovy A, Jana F, Bustos G, Urra F, Smith N, Molgo J, Diehl JA, et al. 2016. Selective vulnerability of cancer cells by inhibition of $\mathrm{Ca}^{2+}$ transfer from endoplasmic reticulum to mitochondria. Cell Rep 15: 219-220. doi:10.1016/j.celrep.2016.03.045

Carnell L, Moore HP. 1994. Transport via the regulated secretory pathway in semi-intact PC12 cells: Role of intracisternal calcium and $\mathrm{pH}$ in the transport and sorting of secretogranin II. J Cell Biol 127: 693-705. doi:10.1083/jcb .127 .3 .693

Chanat E, Huttner WB. 1991. Milieu-induced, selective aggregation of regulated secretory proteins in the trans-Golgi network. J Cell Biol 115: 1505-1519. doi:10.1083/jcb .115 .6 .1505

Chandra S, Kable EP, Morrison GH, Webb WW. 1991. Calcium sequestration in the Golgi apparatus of cultured mammalian cells revealed by laser scanning confocal microscopy and ion microscopy. J Cell Sci 100: 747-752.

Christensen KA, Myers JT, Swanson JA. 2002. pH-dependent regulation of lysosomal calcium in macrophages. J Cell Sci 115: 599-607.

Coe H, Michalak M. 2010. ERp57, a multifunctional endoplasmic reticulum resident oxidoreductase. Int J Biochem Cell Biol 42: 796-799. doi:10.1016/j.biocel.2010.01.009

Coen K, Flannagan RS, Baron S, Carraro-Lacroix LR, Wang D, Vermeire W, Michiels C, Munck S, Baert V, Sugita S, et al. 2012. Lysosomal calcium homeostasis defects, not proton pump defects, cause endo-lysosomal dysfunction in PSEN-deficient cells. J Cell Biol 198: 23-35. doi:10.1083/ jcb.201201076

Corbett EF, Michalak M. 2000. Calcium, a signaling molecule in the endoplasmic reticulum? Trends Biochem Sci 25: 307-311. doi:10.1016/S0968-0004(00)01588-7

Corbett EF, Michalak KM, Oikawa K, Johnson S, Campbell ID, Eggleton P, Kay C, Michalak M. 2000. The conformation of calreticulin is influenced by the endoplasmic reticulum luminal environment. J Biol Chem 275: 27177 27185.

Costa A, Drago I, Zottini M, Pizzo P, Pozzan T. 2013. Peroxisome $\mathrm{Ca}^{2+}$ homeostasis in animal and plant cells. Subcell Biochem 69: 111-133. doi:10.1007/978-94-0076889-5_7

Creighton TE, Hillson DA, Freedman RB. 1980. Catalysis by protein-disulphide isomerase of the unfolding and refolding of proteins with disulphide bonds. J Mol Biol 142: 4362. doi:10.1016/0022-2836(80)90205-3

Crevenna AH, Blank B, Maiser A, Emin D, Prescher J, Beck G, Kienzle C, Bartnik K, Habermann B, Pakdel M, et al. 2016. Secretory cargo sorting by $\mathrm{Ca}^{2+}$-dependent Cab45 oligomerization at the trans-Golgi network. J Cell Biol 213: 305-314. doi:10.1083/jcb.201601089

Csermely P, Miyata Y, Schnaider T, Yahara I. 1995. Autophosphorylation of grp94 (endoplasmin). J Biol Chem 270: 6381-6388. doi:10.1074/jbc.270.11.6381

Csordas G, Varnai P, Golenar T, Roy S, Purkins G, Schneider TG, Balla T, Hajnoczky G. 2010. Imaging interorganelle contacts and local calcium dynamics at the ER-mitochondrial interface. Mol Cell 39: 121-132. doi:10.1016/j.molcel .2010 .06 .029

Davis LC, Platt FM, Galione A. 2015. Preferential coupling of the NAADP pathway to exocytosis in T-cells. Messenger (Los Angel) 4: 53-66. doi:10.1166/msr.2015.1040

de Alba E, Tjandra N. 2004. Structural studies on the $\mathrm{Ca}^{2+}$ binding domain of human nucleobindin (calnuc). Biochemistry 43: 10039-10049. doi:10.1021/bi049310a

Decuypere JP, Bultynck G, Parys JB. 2011. A dual role for $\mathrm{Ca}^{2+}$ in autophagy regulation. Cell Calcium 50: 242-250. doi:10.1016/j.ceca.2011.04.001

Deniaud A, Sharaf el dein O, Maillier E, Poncet D, Kroemer G, Lemaire L, Brenner C. 2008. Endoplasmic reticulum stress induces calcium-dependent permeability transition, mitochondrial outer membrane permeabilization and apoptosis. Oncogene 27: 285-299. doi:10.1038/sj .onc. 1210638

De Stefani D, Rizzuto R, Pozzan T. 2016. Enjoy the trip: Calcium in mitochondria back and forth. Annu Rev Biochem 85: 161-192. doi:10.1146/annurev-biochem060614-034216

Dicks N, Gutierrez K, Michalak M, Bordignon V, Agellon LB. 2015. Endoplasmic reticulum stress, genome damage, and cancer. Front Oncol 5: 11. doi:10.3389/fonc.2015 .00011

Divet A, Paesante S, Grasso C, Cavagna D, Tiveron C, Paolini C, Protasi F, Huchet-Cadiou C, Treves S, Zorzato F. 2007. Increased $\mathrm{Ca}^{2+}$ storage capacity of the skeletal muscle sarcoplasmic reticulum of transgenic mice over-expressing membrane bound calcium binding protein junctate. J Cell Physiol 213: 464-474. doi:10.1002/jcp.21121

Ellgaard L, Riek R, Braun D, Herrmann T, Helenius A, Wüthrich K. 2001. Three-dimensional structure topology of the calreticulin P-domain based on NMR assignment. FEBS Lett 488: 69-73. doi:10.1016/S0014-5793(00) 02382-6

Ellgaard L, Bettendorff P, Braun D, Herrmann T, Fiorito F, Jelesarov I, Guntert P, Helenius A, Wuthrich K. 2002. NMR structures of 36 and 73-residue fragments of the calreticulin P-domain. J Mol Biol 322: 773-784. doi:10 $.1016 /$ S0022-2836(02)00812-4

Faggioni M, Kryshtal DO, Knollmann BC. 2012. Calsequestrin mutations and catecholaminergic polymorphic ventricular tachycardia. Pediatr Cardiol 33: 959-967. doi:10.1007/s00246-012-0256-1

Fan GC, Gregory KN, Zhao W, Park WJ, Kranias EG. 2004. Regulation of myocardial function by histidine-rich, calcium-binding protein. Am J Physiol Heart Circ Physiol 287: H1705-H1711. doi:10.1152/ajpheart.01211.2003

Feske S, Gwack Y, Prakriya M, Srikanth S, Puppel SH, Tanasa B, Hogan PG, Lewis RS, Daly M, Rao A. 2006. A mutation in Orail causes immune deficiency by abrogating CRAC channel function. Nature 441: 179-185. doi:10.1038/na ture04702 
Filadi R, Pozzan T. 2015. Generation and functions of second messengers microdomains. Cell Calcium 58: 405-414. doi:10.1016/j.ceca.2015.03.007

Franzini-Armstrong C, Kenney LJ, Varriano-Marston E. 1987. The structure of calsequestrin in triads of vertebrate skeletal muscle: A deep-etch study. J Cell Biol 105: 49-56. doi:10.1083/jcb.105.1.49

Freedman RB, Hirst TR, Tuite MF. 1994. Protein disulphide isomerase: Building bridges in protein folding. Trends Biochem Sci 19: 331-336. doi:10.1016/0968-0004(94) 90072-8

Frickel EM, Riek R, Jelesarov I, Helenius A, Wuthrich K, Ellgaard L. 2002. TROSY-NMR reveals interaction between ERp57 and the tip of the calreticulin P-domain. Proc Natl Acad Sci 99: 1954-1959. doi:10.1073/pnas .042699099

Galione A. 2015. A primer of NAADP-mediated $\mathrm{Ca}^{2+}$ signalling: From sea urchin eggs to mammalian cells Cell Calcium 58: 27-47. doi:10.1016/j.ceca.2014.09.010

Gaut JR, Hendershot LM. 1993. Mutations within the nucleotide binding site of immunoglobulin-binding protein inhibit ATPase activity and interfere with release of immunoglobulin heavy chain. J Biol Chem 268: 7248-7255.

Gelebart P, Opas M, Michalak M. 2005. Calreticulin, a $\mathrm{Ca}^{2+}$. binding chaperone of the endoplasmic reticulum. Int $\mathrm{J}$ Biochem Cell Biol 37: 260-266. doi:10.1016/j.biocel.2004 .02 .030

Genazzani AA, Galione A. 1996. Nicotinic acid-adenine dinucleotide phosphate mobilizes $\mathrm{Ca}^{2+}$ from a thapsigargin-insensitive pool. Biochem J 315: 721-725. doi:10 $.1042 / \mathrm{bj} 3150721$

Gerasimenko JV, Tepikin AV, Petersen OH, Gerasimenko OV. 1998. Calcium uptake via endocytosis with rapid release from acidifying endosomes. Curr Biol 8: 13351338. doi:10.1016/S0960-9822(07)00565-9

Gerasimenko JV, Maruyama Y, Yano K, Dolman NJ, Tepikin AV, Petersen OH, Gerasimenko OV. 2003. NAADP mobilizes $\mathrm{Ca}^{2+}$ from a thapsigargin-sensitive store in the nuclear envelope by activating ryanodine receptors. J Cell Biol 163: 271-282. doi:10.1083/jcb.200306134

Giacomello M, Drago I, Bortolozzi M, Scorzeto M, Gianelle A, Pizzo P, Pozzan T. 2010. $\mathrm{Ca}^{2+}$ hot spots on the mitochondrial surface are generated by $\mathrm{Ca}^{2+}$ mobilization from stores, but not by activation of store-operated $\mathrm{Ca}^{2+}$ channels. Mol Cell 38: 280-290. doi:10.1016/j.molcel 2010.04.003

Gilabert JA, Parekh AB. 2000. Respiring mitochondria determine the pattern of activation and inactivation of the store-operated $\mathrm{Ca}^{2+}$ current $\mathrm{I}_{\mathrm{CRAC}}$. EMBO J 19: 6401-6407. doi:10.1093/emboj/19.23.6401

Goldberger RF, Epstein CJ, Anfinsen CB. 1963. Acceleration of reactivation of reduced bovine pancreatic ribonuclease by a microsomal system from rat liver. J Biol Chem 238: 628-635.

Gregory KN, Ginsburg KS, Bodi I, Hahn H, Marreez YM, Song Q, Padmanabhan PA, Mitton BA, Waggoner JR, Del Monte F, et al. 2006. Histidine-rich Ca binding protein: A regulator of sarcoplasmic reticulum calcium sequestration and cardiac function. J Mol Cell Cardiol 40: 653-665. doi:10.1016/j.yjmcc.2006.02.003

Griffiths EJ, Rutter GA. 2009. Mitochondrial calcium as a key regulator of mitochondrial ATP production in mammalian cells. Biochim Biophys Acta 1787: 13241333. doi:10.1016/j.bbabio.2009.01.019

Groenendyk J, Agellon LB, Michalak M. 2013. Coping with endoplasmic reticulum stress in the cardiovascular system. Annu Rev Physiol 75: 49-67. doi:10.1146/annurevphysiol-030212-183707

Groenendyk J, Peng Z, Dudek E, Fan X, Mizianty MJ, Dufey E, Urra H, Sepulveda D, Rojas-Rivera D, Lim Y, et al. 2014. Interplay between the oxidoreductase PDIA6 and microRNA-322 controls the response to disrupted endoplasmic reticulum calcium homeostasis. Sci Signal 7: ra54. doi:10.1126/scisignal.2004983

Guido D, Demaurex N, Nunes P. 2015. Junctate boosts phagocytosis by recruiting endoplasmic reticulum $\mathrm{Ca}^{2+}$ stores near phagosomes. J Cell Sci 128: 4074-4082. doi:10 $.1242 /$ jcs. 172510

Guo L, Nakamura K, Lynch J, Opas M, Olson EN, Agellon LB, Michalak M. 2002. Cardiac-specific expression of calcineurin reverses embryonic lethality in calreticulindeficient mouse. J Biol Chem 277: 50776-50779. doi:10 .1074/jbc.M209900200

Gutiérrez T, Simmen T. 2018. Endoplasmic reticulum chaperones tweak the mitochondrial calcium rheostat to control metabolism and cell death. Cell Calcium 70: 64-75. doi:10.1016/j.ceca.2017.05.015

Györke S, Stevens SC, Terentyev D. 2009. Cardiac calsequestrin: Quest inside the SR.J Physiol 587: 3091-3094. doi:10 .1113 /jphysiol.2009.172049

Haigh NG, Johnson AE. 2002. A new role for BiP: Closing the aqueous translocon pore during protein integration into the ER membrane. J Cell Biol 156: 261-270. doi:10 $.1083 /$ jcb. 200110074

Hajnoczky G, Hager R, Thomas AP. 1999. Mitochondria suppress local feedback activation of inositol 1,4,5trisphosphate receptors by $\mathrm{Ca}^{2+}$. J Biol Chem 274: 14157-14162. doi:10.1074/jbc.274.20.14157

Hammadi M, Oulidi A, Gackiere F, Katsogiannou M, Slomianny C, Roudbaraki M, Dewailly E, Delcourt P, Lepage G, Lotteau S, et al. 2013. Modulation of ER stress and apoptosis by endoplasmic reticulum calcium leak via translocon during unfolded protein response: Involvement of GRP78. FASEB J 27: 1600-1609. doi:10.1096/fj $.12-218875$

Hetz C, Papa FR. 2018. The unfolded protein response and cell fate control. Mol Cell 69: 169-181. doi:10.1016/j molcel.2017.06.017

Higo T, Hattori M, Nakamura T, Natsume T, Michikawa T, Mikoshiba K. 2005. Subtype-specific and ER lumenal environment-dependent regulation of inositol 1,4,5trisphosphate receptor type 1 by ERp44. Cell 120: 8598. doi:10.1016/j.cell.2004.11.048

Higo T, Hamada K, Hisatsune C, Nukina N, Hashikawa T, Hattori M, Nakamura T, Mikoshiba K. 2010. Mechanism of ER stress-induced brain damage by $\mathrm{IP}_{3}$ receptor. Neuron 68: 865-878. doi:10.1016/j.neuron.2010.11.010

Hockey LN, Kilpatrick BS, Eden ER, Lin-Moshier Y, Brailoiu GC, Brailoiu E, Futter CE, Schapira AH, Marchant JS, Patel S. 2015. Dysregulation of lysosomal morphology by pathogenic LRRK2 is corrected by TPC2 inhibition. J Cell Sci 128: 232-238. doi:10.1242/jcs. 164152

Hofmann SL, Goldstein JL, Orth K, Moomaw CR, Slaughter CA, Brown MS. 1989. Molecular cloning of a histidine- 
W.-A. Wang et al.

rich $\mathrm{Ca}^{2+}$-binding protein of sarcoplasmic reticulum that contains highly conserved repeated elements. J Biol Chem 264: 18083-18090.

Hohenegger M, Suko J, Gscheidlinger R, Drobny H, Zidar A. 2002. Nicotinic acid-adenine dinucleotide phosphate activates the skeletal muscle ryanodine receptor. Biochem $J$ 367: 423-431. doi:10.1042/bj20020584

Hong CS, Kwon SJ, Cho MC, Kwak YG, Ha KC, Hong B, Li $\mathrm{H}$, Chae SW, Chai OH, Song CH, et al. 2008. Overexpression of junctate induces cardiac hypertrophy and arrhythmia via altered calcium handling. J Mol Cell Cardiol 44: 672-682. doi:10.1016/j.yjmcc.2008.01.012

Honore B, Vorum H. 2000. The CREC family, a novel family of multiple EF-hand, low-affinity $\mathrm{Ca}^{2+}$-binding proteins localised to the secretory pathway of mammalian cells. FEBS Lett 466: 11-18. doi:10.1016/S0014-5793(99) 01780-9

Hoth M, Fanger CM, Lewis RS. 1997. Mitochondrial regulation of store-operated calcium signaling in T lymphocytes. J Cell Biol 137: 633-648. doi:10.1083/jcb.137.3.633

Hou X, Pedi L, Diver MM, Long SB. 2012. Crystal structure of the calcium release-activated calcium channel Orai. Science 338: 1308-1313. doi:10.1126/science. 1228757

Huotari J, Helenius A. 2011. Endosome maturation. EMBO J 30: 3481-3500. doi:10.1038/emboj.2011.286

Ikemoto N, Nagy B, Bhatnagar GM, Gergely J. 1974. Studies on a metal-binding protein of the sarcoplasmic reticulum. J Biol Chem 249: 2357-2365.

Ivessa NE, De Lemos-Chiarandini C, Gravotta D, Sabatini DD, Kreibich G. 1995. The brefeldin A-induced retrograde transport from the Golgi apparatus to the endoplasmic reticulum depends on calcium sequestered to intracellular stores. J Biol Chem 270: 25960-25967. doi:10.1074/jbc.270.43.25960

Jiao Q, Bai Y, Akaike T, Takeshima H, Ishikawa Y, Minamisawa S. 2009. Sarcalumenin is essential for maintaining cardiac function during endurance exercise training. $A m J$ Physiol Heart Circ Physiol 297: H576-H582. doi:10.1152/ ajpheart.00946.2008

Jiao Q, Takeshima H, Ishikawa Y, Minamisawa S. 2012. Sarcalumenin plays a critical role in age-related cardiac dysfunction due to decreases in SERCA2a expression and activity. Cell Calcium 51: 31-39. doi:10.1016/j.ceca.2011 .10 .003

Joshi AS, Zhang H, Prinz WA. 2017. Organelle biogenesis in the endoplasmic reticulum. Nat Cell Biol 19: 876-882. doi:10.1038/ncb3579

Jung J, Michalak M, Agellon LB. 2017. Endoplasmic reticulum malfunction in the nervous system. Front Neurosci 11: 220. doi:10.3389/fnins.2017.00220

Kapoor M, Ellgaard L, Gopalakrishnapai J, Schirra C, Gemma E, Oscarson S, Helenius A, Surolia A. 2004. Mutational analysis provides molecular insight into the carbohydrate-binding region of calreticulin: Pivotal roles of tyrosine-109 and aspartate-135 in carbohydrate recognition. Biochemistry 43: 97-106. doi:10.1021/bi0355286

Karabinos A, Bhattacharya D, Morys-Wortmann C, Kroll K, Hirschfeld G, Kratzin HD, Barnikol-Watanabe S, Hilschmann N. 1996. The divergent domains of the NEFA and nucleobindin proteins are derived from an EF-hand ancestor. Mol Biol Evol 13: 990-998. doi:10.1093/oxfordjour nals.molbev.a025667
Kassenbrock CK, Kelly RB. 1989. Interaction of heavy chain binding protein (BiP/GRP78) with adenine nucleotides. EMBO J 8: 1461-1467. doi:10.1002/j.1460-2075.1989 .tb03529.x

Kilpatrick BS, Eden ER, Schapira AH, Futter CE, Patel S. 2013. Direct mobilisation of lysosomal $\mathrm{Ca}^{2+}$ triggers complex $\mathrm{Ca}^{2+}$ signals. J Cell Sci 126: $60-66$. doi:10.1242/jcs .118836

Kilpatrick BS, Yates E, Grimm C, Schapira AH, Patel S. 2016. Endo-lysosomal TRP mucolipin-1 channels trigger global ER $\mathrm{Ca}^{2+}$ release and $\mathrm{Ca}^{2+}$ influx. J Cell Sci 129: 3859-3867. doi:10.1242/jcs.190322

Kim E, Shin DW, Hong CS, Jeong D, Kim DH, Park WJ. 2003. Increased $\mathrm{Ca}^{2+}$ storage capacity in the sarcoplasmic reticulum by overexpression of HRC (histidine-rich $\mathrm{Ca}^{2+}$ binding protein). Biochem Biophys Res Commun 300: 192-196. doi:10.1016/S0006-291X(02)02829-2

Kirichok Y, Krapivinsky G, Clapham DE. 2004. The mitochondrial calcium uniporter is a highly selective ion channel. Nature 427: 360-364. doi:10.1038/nature02246

Knollmann BC. 2009. New roles of calsequestrin and triadin in cardiac muscle. J Physiol 587: 3081-3087. doi:10.1113/ jphysiol.2009.172098

Knollmann BC, Chopra N, Hlaing T, Akin B, Yang T, Ettensohn K, Knollmann BE, Horton KD, Weissman NJ, Holinstat I, et al. 2006. Casq2 deletion causes sarcoplasmic reticulum volume increase, premature $\mathrm{Ca}^{2+}$ release, and catecholaminergic polymorphic ventricular tachycardia. JClin Invest 116: 2510-2520. doi:10.1172/jci29128

Krebs J, Agellon LB, Michalak M. 2015. $\mathrm{Ca}^{2+}$ homeostasis and endoplasmic reticulum (ER) stress: An integrated view of calcium signaling. Biochem Biophys Res Commun 460: 114-121. doi:10.1016/j.bbrc.2015.02.004

Kumar A, Chakravarty H, Bal NC, Balaraju T, Jena N, Misra G, Bal C, Pieroni E, Periasamy M, Sharon A. 2013. Identification of calcium binding sites on calsequestrin 1 and their implications for polymerization. Mol Biosyst 9: 1949-1957. doi:10.1039/c3mb25588c

Kwon SJ, Kim DH. 2009. Characterization of junctateSERCA2a interaction in murine cardiomyocyte. Biochem Biophys Res Commun 390: 1389-1394. doi:10.1016/j.bbrc .2009.10.165

Lamb HK, Mee C, Xu W, Liu L, Blond S, Cooper A, Charles IG, Hawkins AR. 2006. The affinity of a major $\mathrm{Ca}^{2+}$ binding site on GRP78 is differentially enhanced by ADP and ATP. J Biol Chem 281: 8796-8805. doi:10.1074/jbc .M503964200

Larkin H, Costantino S, Seaman MN, Lavoie C. 2016. Calnuc function in endosomal sorting of lysosomal receptors. Traffic 17: 416-432. doi:10.1111/tra.12374

Lasorsa FM, Pinton P, Palmieri L, Scarcia P, Rottensteiner H, Rizzuto R, Palmieri F. 2008. Peroxisomes as novel players in cell calcium homeostasis. J Biol Chem 283: 1530015308. doi:10.1074/jbc.M800648200

Leach MR, Cohen-Doyle MF, Thomas DY, Williams DB. 2002. Localization of the lectin, ERp57 binding, and polypeptide binding sites of calnexin and calreticulin. J Biol Chem 277: 29686-29697. doi:10.1074/jbc.M202405200

Lebeche D, Kaminer B. 1992. Characterization of a calsequestrin-like protein from sea-urchin eggs. Biochem J 287: 741-747. doi:10.1042/bj2870741 
Lebeche D, Lucero HA, Kaminer B. 1994. Calcium binding properties of rabbit liver protein disulfide isomerase. Biochem Biophys Res Commun 202: 556-561. doi:10.1006/ bbrc.1994.1964

Leberer E, Charuk JH, Green NM, MacLennan DH. 1989. Molecular cloning and expression of cDNA encoding a lumenal calcium binding glycoprotein from sarcoplasmic reticulum. Proc Natl Acad Sci 86: 6047-6051. doi:10 $.1073 /$ pnas.86.16.6047

Leberer E, Timms BG, Campbell KP, MacLennan DH. 1990. Purification, calcium binding properties, and ultrastructural localization of the 53,000- and 160,000 (sarcalumenin)-Dalton glycoproteins of the sarcoplasmic reticulum. J Biol Chem 265: 10118-10124.

Lee AS. 1992. Mammalian stress response: Induction of the glucose-regulated protein family. Curr Opin Cell Biol 4: 267-273. doi:10.1016/0955-0674(92)90042-B

Lee HC, Aarhus R. 1995. A derivative of NADP mobilizes calcium stores insensitive to inositol trisphosphate and cyclic ADP-ribose. J Biol Chem 270: 2152-2157. doi:10 $.1074 / j b c .270 .5 .2152$

Lee HG, Kang H, Kim DH, Park WJ. 2001. Interaction of HRC (histidine-rich $\mathrm{Ca}^{2+}$-binding protein) and triadin in the lumen of sarcoplasmic reticulum. J Biol Chem 276: 39533-39538. doi:10.1074/jbc.M010664200

Li Y, Camacho P. 2004. $\mathrm{Ca}^{2+}$-dependent redox modulation of SERCA2b by ERp57. J Cell Biol 164: 35-46. doi:10 $.1083 /$ jcb. 200307010

Li HT, Yan JB, Li J, Zhou MH, Zhu XD, Zhang YX, Tien P. 2005. Enhancement of humoral immune responses to HBsAg by heat shock protein gp96 and its N-terminal fragment in mice. World J Gastroenterol 11: 2858-2863. doi:10.3748/wjg.v11.i19.2858

Lievremont JP, Rizzuto R, Hendershot L, Meldolesi J. 1997. $\mathrm{BiP}$, a major chaperone protein of the endoplasmic reticulum lumen, plays a direct and important role in the storage of the rapidly exchanging pool of $\mathrm{Ca}^{2+}$. J Biol Chem 272: 30873-30879. doi:10.1074/jbc.272.49.30873

Lin P, Le-Niculescu H, Hofmeister R, McCaffery JM, Jin M, Hennemann H, McQuistan T, De Vries L, Farquhar MG. 1998. The mammalian calcium-binding protein, nucleobindin (CALNUC), is a Golgi resident protein. J Cell Biol 141: 1515-1527. doi:10.1083/jcb.141.7.1515

Lin P, Yao Y, Hofmeister R, Tsien RY, Farquhar MG. 1999. Overexpression of CALNUC (nucleobindin) increases agonist and thapsigargin releasable $\mathrm{Ca}^{2+}$ storage in the Golgi. J Cell Biol 145: 279-289. doi:10.1083/jcb.145.2.279

Lin-Moshier Y, Keebler MV, Hooper R, Boulware MJ, Liu X, Churamani D, Abood ME, Walseth TF, Brailoiu E, Patel S, et al. 2014. The two-pore channel (TPC) interactome unmasks isoform-specific roles for TPCs in endolysosomal morphology and cell pigmentation. Proc Natl Acad Sci 111: 13087-13092. doi:10.1073/pnas.1407004111

Liou J, Kim ML, Heo WD, Jones JT, Myers JW, Ferrell JE Jr, Meyer T. 2005. STIM is a $\mathrm{Ca}^{2+}$ sensor essential for $\mathrm{Ca}^{2+}$-store-depletion-triggered $\mathrm{Ca}^{2+}$ influx. Curr Biol 15: 1235-1241. doi:10.1016/j.cub.2005.05.055

Little E, Lee AS. 1995. Generation of a mammalian cell line deficient in glucose-regulated protein stress induction through targeted ribozyme driven by a stress-inducible promoter. J Biol Chem 270: 9526-9534. doi:10.1074/jbc .270 .16 .9526
Liu H, Bowes RC III, van de Water B, Sillence C, Nagelkerke JF, Stevens JL. 1997. Endoplasmic reticulum chaperones GRP78 and calreticulin prevent oxidative stress, $\mathrm{Ca}^{2+}$ disturbances, and cell death in renal epithelial cells. J Biol Chem 272: 21751-21759. doi:10.1074/jbc.272.35.21751

Lloyd-Evans E, Morgan AJ, He X, Smith DA, Elliot-Smith E, Sillence DJ, Churchill GC, Schuchman EH, Galione A, Platt FM. 2008. Niemann-Pick disease type C1 is a sphingosine storage disease that causes deregulation of lysosomal calcium. Nat Med 14: 1247-1255. doi:10.1038/ nm.1876

Lopez-Sanjurjo CI, Tovey SC, Prole DL, Taylor CW. 2013. Lysosomes shape Ins $(1,4,5) P_{3}$-evoked $\mathrm{Ca}^{2+}$ signals by selectively sequestering $\mathrm{Ca}^{2+}$ released from the endoplasmic reticulum. J Cell Sci 126: 289-300. doi:10.1242/jcs.116103

Lucero HA, Kaminer B. 1999. The role of calcium on the activity of ERcalcistorin/protein-disulfide isomerase and the significance of the C-terminal and its calcium binding. A comparison with mammalian protein-disulfide isomerase. J Biol Chem 274: 3243-3251. doi:10.1074/jbc .274.5.3243

Lucero HA, Lebeche D, Kaminer B. 1998. ERcalcistorin/protein-disulfide isomerase acts as a calcium storage protein in the endoplasmic reticulum of a living cell. Comparison with calreticulin and calsequestrin. J Biol Chem 273: 9857-9863. doi:10.1074/jbc.273.16.9857

Lynch J, Guo L, Gelebart P, Chilibeck K, Xu J, Molkentin JD, Agellon LB, Michalak M. 2005. Calreticulin signals upstream of calcineurin and MEF2C in a critical $\mathrm{Ca}^{2+}$-dependent signaling cascade. J Cell Biol 170: 37-47. doi:10 $.1083 /$ jcb. 200412156

Macer DR, Koch GL. 1988. Identification of a set of calciumbinding proteins in reticuloplasm, the luminal content of the endoplasmic reticulum. J Cell Sci 91: 61-70.

MacLennan DH, Wong PT. 1971. Isolation of a calciumsequestering protein from sarcoplasmic reticulum. Proc Natl Acad Sci 68: 1231-1235. doi:10.1073/pnas.68.6.1231

Manno C, Figueroa LC, Gillespie D, Fitts R, Kang C, Franzini-Armstrong C, Rios E. 2017. Calsequestrin depolymerizes when calcium is depleted in the sarcoplasmic reticulum of working muscle. Proc Natl Acad Sci 114: E638-E647. doi:10.1073/pnas.1620265114

Marzec M, Eletto D, Argon Y. 2012. GRP94: An HSP90-like protein specialized for protein folding and quality control in the endoplasmic reticulum. Biochim Biophys Acta 1823: 774-787. doi:10.1016/j.bbamcr.2011.10.013

Mekahli D, Bultynck G, Parys JB, De Smedt H, Missiaen L. 2011. Endoplasmic-reticulum calcium depletion and disease. Cold Spring Harb Perspect Biol 3: a004317. doi:10 $.1101 /$ cshperspect.a004317

Melchionda M, Pittman JK, Mayor R, Patel S. 2016. $\mathrm{Ca}^{2+} / \mathrm{H}^{+}$ exchange by acidic organelles regulates cell migration in vivo. J Cell Biol 212: 803-813. doi:10.1083/jcb.201510019

Melnick J, Dul JL, Argon Y. 1994. Sequential interaction of the chaperones BiP and GRP94 with immunoglobulin chains in the endoplasmic reticulum. Nature 370: 373375. doi:10.1038/370373a0

Mery L, Mesaeli N, Michalak M, Opas M, Lew DP, Krause KH. 1996. Overexpression of calreticulin increases intracellular $\mathrm{Ca}^{2+}$ storage and decreases store-operated $\mathrm{Ca}^{2+}$ influx. J Biol Chem 271: 9332-9339. doi:10.1074/jbc.271 .16 .9332 
W.-A. Wang et al.

Mesaeli N, Nakamura K, Zvaritch E, Dickie P, Dziak E, Krause KH, Opas M, MacLennan DH, Michalak M. 1999. Calreticulin is essential for cardiac development. J Cell Biol 144: 857-868. doi:10.1083/jcb.144.5.857

Micaroni M, Perinetti G, Berrie CP, Mironov AA. 2010. The SPCA1 $\mathrm{Ca}^{2+}$ pump and intracellular membrane trafficking. Traffic 11: 1315-1333. doi:10.1111/j.1600-0854.2010 .01096.x

Michalak M, Opas M. 2009. Endoplasmic and sarcoplasmic reticulum in the heart. Trends Cell Biol 19: 253-259. doi:10.1016/j.tcb.2009.03.006

Mignen O, Thompson JL, Shuttleworth TJ. 2008. Orail subunit stoichiometry of the mammalian CRAC channel pore. J Physiol 586: 419-425. doi:10.1113/jphysiol.2007 .147249

Miura K, Titani K, Kurosawa Y, Kanai Y. 1992. Molecular cloning of nucleobindin, a novel DNA-binding protein that contains both a signal peptide and a leucine zipper structure. Biochem Biophys Res Commun 187: 375-380. doi:10.1016/S0006-291X(05)81503-7

Mojzisova A, Krizanova O, Zacikova L, Kominkova V, Ondrias K. 2001. Effect of nicotinic acid adenine dinucleotide phosphate on ryanodine calcium release channel in heart. Pflugers Arch 441: 674-677. doi:10.1007/ s004240000465

Morciano G, Marchi S, Morganti C, Sbano L, Bittremieux M, Kerkhofs M, Corricelli M, Danese A, KarkucinskaWieckowska A, Wieckowski MR, et al. 2018. Role of mitochondria-associated ER membranes in calcium regulation in cancer-specific settings. Neoplasia 20: 510-523. doi:10.1016/j.neo.2018.03.005

Morel-Huaux VM, Pypaert M, Wouters S, Tartakoff AM, Jurgan U, Gevaert K, Courtoy PJ. 2002. The calciumbinding protein $\mathrm{p} 54 / \mathrm{NEFA}$ is a novel luminal resident of medial Golgi cisternae that traffics independently of mannosidase II. Eur J Cell Biol 81: 87-100. doi:10.1078/ 0171-9335-00224

Morgan AJ, Davis LC, Wagner SK, Lewis AM, Parrington J, Churchill GC, Galione A. 2013. Bidirectional $\mathrm{Ca}^{2+}$ signaling occurs between the endoplasmic reticulum and acidic organelles. J Cell Biol 200: 789-805. doi:10.1083/jcb .201204078

Muik M, Frischauf I, Derler I, Fahrner M, Bergsmann J, Eder P, Schindl R, Hesch C, Polzinger B, Fritsch R, et al. 2008. Dynamic coupling of the putative coiled-coil domain of ORAI1 with STIM1 mediates ORAI1 channel activation. $J$ Biol Chem 283: 8014-8022. doi:10.1074/jbc.M708898200

Nakamura K, Zuppini A, Arnaudeau S, Lynch J, Ahsan I, Krause R, Papp S, De Smedt H, Parys JB, Muller-Esterl W, et al. 2001. Functional specialization of calreticulin domains. J Cell Biol 154: 961-972. doi:10.1083/jcb .200102073

Nesselhut J, Jurgan U, Onken E, Götz H, Barnikol HU, Hirschfeld G, Barnikol-Watanabe S, Hilschmann N. 2001. Golgi retention of human protein NEFA is mediated by its N-terminal Leu/lle-rich region. FEBS Lett 509: 469-475. doi:10.1016/S0014-5793(01)03187-8

Nunes-Hasler P, Demaurex N. 2017. The ER phagosome connection in the era of membrane contact sites. Biochim Biophys Acta 1864: 1513-1524. doi:10.1016/j.bbamcr .2017 .04 .007
Nwokonko RM, Cai X, Loktionova NA, Wang Y, Zhou Y, Gill DL. 2017. The STIM-Orai pathway: Conformational coupling between STIM and Orai in the activation of store-operated $\mathrm{Ca}^{2+}$ entry. Adv Exp Med Biol 993: 83-98. doi:10.1007/978-3-319-57732-6_5

Oberdorf JA, Lebeche D, Head JF, Kaminer B. 1988. Identification of a calsequestrin-like protein from sea urchin eggs. J Biol Chem 263: 6806-6809. doi:10.1042/bj2870741

Oda K. 1992. Calcium depletion blocks proteolytic cleavages of plasma protein precursors which occur at the Golgi and/or trans-Golgi network. Possible involvement of $\mathrm{Ca}^{2+}$-dependent Golgi endoproteases. J Biol Chem 267: 17465-17471.

Ouyang YG, Xu LJ, Emery JF, Lee AS, Giffard RG. 2011. Overexpressing GRP78 influences $\mathrm{Ca}^{2+}$ handling and function of mitochondria in astrocytes after ischemialike stress. Mitochondrion 11: 279-286. doi:10.1016/j .mito.2010.10.007

Paolini C, Quarta M, Nori A, Boncompagni S, Canato M, Volpe P, Allen PD, Reggiani C, Protasi F. 2007. Reorganized stores and impaired calcium handling in skeletal muscle of mice lacking calsequestrin-1. J Physiol 583: 767-784. doi:10.1113/jphysiol.2007.138024

Park CY, Hoover PJ, Mullins FM, Bachhawat P, Covington ED, Raunser S, Walz T, Garcia KC, Dolmetsch RE, Lewis RS. 2009. STIM1 clusters and activates CRAC channels via direct binding of a cytosolic domain to Orail. Cell 136: 876-890. doi:10.1016/j.cell.2009.02.014

Park CS, Chen S, Lee H, Cha H, Oh JG, Hong S, Han P, Ginsburg KS, Jin S, Park I, et al. 2013. Targeted ablation of the histidine-rich $\mathrm{Ca}^{2+}$-binding protein (HRC) gene is associated with abnormal SR $\mathrm{Ca}^{2+}$-cycling and severe pathology under pressure-overload stress. Basic Res Cardiol 108: 344. doi:10.1007/s00395-013-0344-2

Patel S, Muallem S. 2011. Acidic $\mathrm{Ca}^{2+}$ stores come to the fore. Cell Calcium 50: 109-112. doi:10.1016/j.ceca.2011.03.009

Peinelt C, Vig M, Koomoa DL, Beck A, Nadler MJ, KoblanHuberson M, Lis A, Fleig A, Penner R, Kinet JP. 2006. Amplification of CRAC current by STIM1 and CRACM1 (Orai1). Nat Cell Biol 8: 771-773. doi:10.1038/ncb1435

Penna A, Demuro A, Yeromin AV, Zhang SL, Safrina O, Parker I, Cahalan MD. 2008. The CRAC channel consists of a tetramer formed by Stim-induced dimerization of Orai dimers. Nature 456: 116-120. doi:10.1038/nature 07338

Penny CJ, Kilpatrick BS, Eden ER, Patel S. 2015. Coupling acidic organelles with the ER through $\mathrm{Ca}^{2+}$ microdomains at membrane contact sites. Cell Calcium 58: $387-$ 396. doi:10.1016/j.ceca.2015.03.006

Pezzati R, Bossi M, Podini P, Meldolesi J, Grohovaz F. 1997. High-resolution calcium mapping of the endoplasmic reticulum-Golgi-exocytic membrane system. Electron energy loss imaging analysis of quick frozen-freeze dried PC12 cells. Mol Biol Cell 8: 1501-1512. doi:10.1091/ mbc.8.8.1501

Phillips MJ, Voeltz GK. 2016. Structure and function of ER membrane contact sites with other organelles. Nat Rev Mol Cell Biol 17: 69-82. doi:10.1038/nrm.2015.8

Picello E, Damiani E, Margreth A. 1992. Low-affinity $\mathrm{Ca}^{2+}$ binding sites versus $\mathrm{Zn}^{2+}$-binding sites in histidine-rich $\mathrm{Ca}^{2+}$-binding protein of skeletal muscle sarcoplasmic 
reticulum. Biochem Biophys Res Commun 186: 659-667. doi:10.1016/0006-291X(92)90797-O

Pinton P, Pozzan T, Rizzuto R. 1998. The Golgi apparatus is an inositol 1,4,5-trisphosphate-sensitive $\mathrm{Ca}^{2+}$ store, with functional properties distinct from those of the endoplasmic reticulum. EMBO J 17: 5298-5308. doi:10.1093/em boj/17.18.5298

Poirier S, Mamarbachi M, Chen WT, Lee AS, Mayer G. 2015. GRP94 regulates circulating cholesterol levels through blockade of PCSK9-induced LDLR degradation. Cell Rep 13: 2064-2071. doi:10.1016/j.celrep.2015.11.006

Prakriya M, Feske S, Gwack Y, Srikanth S, Rao A, Hogan PG. 2006. Orail is an essential pore subunit of the CRAC channel. Nature 443: 230-233. doi:10.1038/nature05122

Prins D, Michalak M. 2011. Organellar calcium buffers. Cold Spring Harb Perspect Biol 3: a004069. doi:10.1101/cshper spect.a004069

Prins D, Groenendyk J, Touret N, Michalak M. 2011. Modulation of STIM1 and capacitative $\mathrm{Ca}^{2+}$ entry by the endoplasmic reticulum luminal oxidoreductase ERp57. EMBO Rep 12: 1182-1188. doi:10.1038/embor.2011.173

Prinz WA. 2014. Bridging the gap: Membrane contact sites in signaling, metabolism, and organelle dynamics. J Cell Biol 205: 759-769. doi:10.1083/jcb.201401126

Prudent J, McBride HM. 2017. The mitochondria-endoplasmic reticulum contact sites: A signalling platform for cell death. Curr Opin Cell Biol 47: 52-63. doi:10.1016/j.ceb .2017 .03 .007

Pryor PR, Mullock BM, Bright NA, Gray SR, Luzio JP. 2000. The role of intraorganellar $\mathrm{Ca}^{2+}$ in late endosome-lysosome heterotypic fusion and in the reformation of lysosomes from hybrid organelles. J Cell Biol 149: 1053-1062. doi:10.1083/jcb.149.5.1053

Randow F, Seed B. 2001. Endoplasmic reticulum chaperone gp96 is required for innate immunity but not cell viability. Nat Cell Biol 3: 891-896. doi:10.1038/ncb1001-891

Rapizzi E, Pinton P, Szabadkai G, Wieckowski MR, Vandecasteele G, Baird G, Tuft RA, Fogarty KE, Rizzuto R. 2002. Recombinant expression of the voltage-dependent anion channel enhances the transfer of $\mathrm{Ca}^{2+}$ microdomains to mitochondria. J Cell Biol 159: 613-624. doi:10.1083/jcb .200205091

Reddy RK, Lu J, Lee AS. 1999. The endoplasmic reticulum chaperone glycoprotein GRP94 with $\mathrm{Ca}^{2+}$-binding and antiapoptotic properties is a novel proteolytic target of calpain during etoposide-induced apoptosis. J Biol Chem 274: 28476-28483. doi:10.1074/jbc.274.40.28476

Rizzuto R, Brini M, Murgia M, Pozzan T. 1993. Microdomains with high $\mathrm{Ca}^{2+}$ close to $\mathrm{IP}_{3}$-sensitive channels that are sensed by neighboring mitochondria. Science 262: 744-747. doi:10.1126/science.8235595

Rizzuto R, Pinton P, Carrington W, Fay FS, Fogarty KE, Lifshitz LM, Tuft RA, Pozzan T. 1998. Close contacts with the endoplasmic reticulum as determinants of mitochondrial $\mathrm{Ca}^{2+}$ responses. Science 280: 1763-1766. doi:10.1126/science.280.5370.1763

Ronco V, Potenza DM, Denti F, Vullo S, Gagliano G, Tognolina M, Guerra G, Pinton P, Genazzani AA, Mapelli L, et al. 2015. A novel $\mathrm{Ca}^{2+}$-mediated cross-talk between endoplasmic reticulum and acidic organelles: Implications for NAADP-dependent $\mathrm{Ca}^{2+}$ signalling. Cell Calcium 57: 89-100. doi:10.1016/j.ceca.2015.01.001
Roos J, DiGregorio PJ, Yeromin AV, Ohlsen K, Lioudyno M, Zhang S, Safrina O, Kozak JA, Wagner SL, Cahalan MD, et al. 2005. STIM1, an essential and conserved component of store-operated $\mathrm{Ca}^{2+}$ channel function. J Cell Biol 169: 435-445. doi:10.1083/jcb.200502019

Rossi AE, Dirksen RT. 2006. Sarcoplasmic reticulum: The dynamic calcium governor of muscle. Muscle Nerve 33: 715-731. doi:10.1002/mus.20512

Ruas M, Davis LC, Chen CC, Morgan AJ, Chuang KT, Walseth TF, Grimm C, Garnham C, Powell T, Platt N, et al. 2015. Expression of $\mathrm{Ca}^{2+}$-permeable two-pore channels rescues NAADP signalling in TPC-deficient cells. $E M B O$ J 34: 1743-1758. doi:10.15252/embj.201490009

Sacchetto R, Damiani E, Turcato F, Nori A, Margreth A. 2001. $\mathrm{Ca}^{2+}$-dependent interaction of triadin with histidine-rich $\mathrm{Ca}^{2+}$-binding protein carboxyl-terminal region. Biochem Biophys Res Commun 289: 1125-1134. doi:10 $.1006 /$ bbrc.2001.6126

Sambrook JF. 1990. The involvement of calcium in transport of secretory proteins from the endoplasmic reticulum. Cell 61: 197-199. doi:10.1016/0092-8674(90)90798-J

Sanchez EJ, Lewis KM, Danna BR, Kang C. 2012. Highcapacity $\mathrm{Ca}^{2+}$ binding of human skeletal calsequestrin J Biol Chem 287: 11592-11601. doi:10.1074/jbc.M111 .335075

Schauble N, Lang S, Jung M, Cappel S, Schorr S, Ulucan O, Linxweiler J, Dudek J, Blum R, Helms V, et al. 2012. BiPmediated closing of the Sec61 channel limits $\mathrm{Ca}^{2+}$ leakage from the ER. EMBO J 31: 3282-3296. doi:10.1038/emboj .2012 .189

Scherer PE, Lederkremer GZ, Williams S, Fogliano M, Baldini G, Lodish HF. 1996. Cab45, a novel $\mathrm{Ca}^{2+}$-binding protein localized to the Golgi lumen. J Cell Biol 133: 257-268. doi:10.1083/jcb.133.2.257

Schrag JD, Bergeron JJ, Li Y, Borisova S, Hahn M, Thomas DY, Cygler M. 2001. The structure of calnexin, an ER chaperone involved in quality control of protein folding. Mol Cell 8: 633-644. doi:10.1016/S1097-2765 (01)00318-5

Shimura M, Minamisawa S, Takeshima H, Jiao Q, Bai Y, Umemura S, Ishikawa Y. 2008. Sarcalumenin alleviates stress-induced cardiac dysfunction by improving $\mathrm{Ca}^{2+}$ handling of the sarcoplasmic reticulum. Cardiovasc Res 77: 362-370. doi:10.1093/cvr/cvm019

Singh A, Chagtoo M, Tiwari S, George N, Chakravarti B, Khan S, Lakshmi S, Godbole MM. 2017. Inhibition of inositol 1, 4, 5-trisphosphate receptor induce breast cancer cell death through deregulated autophagy and cellular bioenergetics. J Cell Biochem 118: 2333-2346. doi:10 $.1002 /$ jcb. 25891

Solovyova N, Fernyhough P, Glazner G, Verkhratsky A. 2002. Xestospongin $\mathrm{C}$ empties the ER calcium store but does not inhibit $\mathrm{InsP}_{3}$-induced $\mathrm{Ca}^{2+}$ release in cultured dorsal root ganglia neurones. Cell Calcium 32: 49-52. doi:10.1016/S0143-4160(02)00094-5

Srikanth S, Jew M, Kim KD, Yee MK, Abramson J, Gwack Y. 2012. Junctate is a $\mathrm{Ca}^{2+}$-sensing structural component of Orail and stromal interaction molecule 1 (STIM1). Proc Natl Acad Sci 109: 8682-8687. doi:10.1073/pnas.120 0667109

Stathopulos PB, Li GY, Plevin MJ, Ames JB, Ikura M. 2006. Stored $\mathrm{Ca}^{2+}$ depletion-induced oligomerization of stro- 
W.-A. Wang et al.

mal interaction molecule 1 (STIM1) via the EF-SAM region: An initiation mechanism for capacitive $\mathrm{Ca}^{2+}$ entry. J Biol Chem 281: 35855-35862. doi:10.1074/jbc .M608247200

Suk JY, Kim YS, Park WJ. 1999. HRC (histidine-rich $\mathrm{Ca}^{2+}$ binding protein) resides in the lumen of sarcoplasmic reticulum as a multimer. Biochem Biophys Res Commun 263: 667-671. doi:10.1006/bbrc.1999.1432

Suzuki CK, Bonifacino JS, Lin AY, Davis MM, Klausner RD. 1991. Regulating the retention of T-cell receptor $\alpha$ chain variants within the endoplasmic reticulum: $\mathrm{Ca}^{2+}$ - dependent association with BiP. J Cell Biol 114: 189-205. doi:10 $.1083 /$ jcb.114.2.189

Szalai G, Csordas G, Hantash BM, Thomas AP, Hajnoczky G. 2000. Calcium signal transmission between ryanodine receptors and mitochondria. J Biol Chem 275: 1530515313. doi:10.1074/jbc.275.20.15305

Tjoelker LW, Seyfried CE, Eddy RL Jr, Byers MG, Shows TB, Calderon J, Schreiber RB, Gray PW. 1994. Human, mouse, and rat calnexin cDNA cloning: Identification of potential calcium binding motifs and gene localization to human chromosome 5. Biochemistry 33: 3229-3236. doi:10.1021/bi00177a013

Tong Y, Song F. 2015. Intracellular calcium signaling regulates autophagy via calcineurin-mediated TFEB dephosphorylation. Autophagy 11: 1192-1195. doi:10.1080/ 15548627.2015.1054594

Treves S, Feriotto G, Moccagatta L, Gambari R, Zorzato F. 2000. Molecular cloning, expression, functional characterization, chromosomal localization, and gene structure of junctate, a novel integral calcium binding protein of sarco(endo)plasmic reticulum membrane. J Biol Chem 275: 39555-39568. doi:10.1074/jbc.M005473200

Treves S, Franzini-Armstrong C, Moccagatta L, Arnoult C, Grasso C, Schrum A, Ducreux S, Zhu MX, Mikoshiba K, Girard T, et al. 2004. Junctate is a key element in calcium entry induced by activation of Ins $\mathrm{P}_{3}$ receptors and/or calcium store depletion. J Cell Biol 166: 537-548. doi:10 $.1083 /$ jcb. 200404079

Van PN, Peter F, Soling HD. 1989. Four intracisternal calcium-binding glycoproteins from rat liver microsomes with high affinity for calcium. No indication for calsequestrinlike proteins in inositol 1,4,5-trisphosphate-sensitive calcium sequestering rat liver vesicles. J Biol Chem 264: 17494-17501.

Van Coppenolle F, Vanden Abeele F, Slomianny C, Flourakis M, Hesketh J, Dewailly E, Prevarskaya N. 2004. Ribosome-translocon complex mediates calcium leakage from endoplasmic reticulum stores. J Cell Sci 117: 4135-4142. doi:10.1242/jcs.01274

Vandecaetsbeek I, Vangheluwe P, Raeymaekers L, Wuytack F, Vanoevelen J. 2011. The $\mathrm{Ca}^{2+}$ pumps of the endoplasmic reticulum and Golgi apparatus. Cold Spring Harb Perspect Biol 3: a004184. doi:10.1101/cshperspect .a004184

Vanoevelen J, Raeymaekers L, Parys JB, De Smedt H, Van Baelen K, Callewaert G, Wuytack F, Missiaen L. 2004 Inositol trisphosphate producing agonists do not mobilize the thapsigargin-insensitive part of the endoplasmicreticulum and Golgi $\mathrm{Ca}^{2+}$ store. Cell Calcium 35: 115121. doi:10.1016/j.ceca.2003.08.003
Vasiljevic M, Heisler FF, Hausrat TJ, Fehr S, Milenkovic I, Kneussel M, Sieghart W. 2012. Spatio-temporal expression analysis of the calcium-binding protein calumenin in the rodent brain. Neuroscience 202: 29-41. doi:10.1016/j .neuroscience.2011.11.069

Vitadello M, Penzo D, Petronilli V, Michieli G, Gomirato S, Menabo R, Di Lisa F, Gorza L. 2003. Overexpression of the stress protein Grp94 reduces cardiomyocyte necrosis due to calcium overload and simulated ischemia. FASEB J 17: 923-925. doi:10.1096/fj.02-0644fje

von Blume J, Alleaume AM, Kienzle C, Carreras-Sureda A, Valverde M, Malhotra V. 2012. Cab45 is required for $\mathrm{Ca}^{2+}$-dependent secretory cargo sorting at the trans-Golgi network. J Cell Biol 199: 1057-1066. doi:10.1083/jcb .201207180

Vorum H, Liu X, Madsen P, Rasmussen HH, Honoré B. 1998. Molecular cloning of a cDNA encoding human calumenin, expression in Escherichia coli and analysis of its $\mathrm{Ca}^{2+}$-binding activity. Biochim Biophys Acta 1386: 121-131. doi:10.1016/S0167-4838(98)00089-2

Vorum H, Hager H, Christensen BM, Nielsen S, Honoré B. 1999. Human calumenin localizes to the secretory pathway and is secreted to the medium. Exp Cell Res 248: 473481. doi:10.1006/excr.1999.4431

Wang M, Kaufman RJ. 2016. Protein misfolding in the endoplasmic reticulum as a conduit to human disease. $\mathrm{Na}$ ture 529: 326-335. doi:10.1038/nature17041

Wang S, Trumble WR, Liao H, Wesson CR, Dunker AK, Kang CH. 1998. Crystal structure of calsequestrin from rabbit skeletal muscle sarcoplasmic reticulum. Nat Struct Biol 5: 476-483. doi:10.1038/nsb0698-476

Wang WA, Liu WX, Durnaoglu S, Lee SK, Lian J, Lehner R, Ahnn J, Agellon LB, Michalak M. 2017. Loss of calreticulin uncovers a critical role for calcium in regulating cellular lipid homeostasis. Sci Rep 7: 5941. doi:10.1038/ s41598-017-05734-x

Wisniewska M, Karlberg T, Lehtio L, Johansson I, Kotenyova T, Moche M, Schuler H. 2010. Crystal structures of the ATPase domains of four human Hsp70 isoforms: HSPA1L/Hsp70-hom, HSPA2/Hsp70-2, HSPA6/ Hsp70B', and HSPA5/BiP/GRP78. PLoS ONE 5: e8625. doi:10.1371/journal.pone.0008625

Wong AK, Capitanio P, Lissandron V, Bortolozzi M, Pozzan T, Pizzo P. 2013. Heterogeneity of $\mathrm{Ca}^{2+}$ handling among and within Golgi compartments. J Mol Cell Biol 5: 266276. doi:10.1093/jmcb/mjt024

Wray S, Burdyga T. 2010. Sarcoplasmic reticulum function in smooth muscle. Physiol Rev 90: 113-178. doi:10.1152/ physrev.00018.2008

Wuytack F, Raeymaekers L, Missiaen L. 2003. PMR1/SPCA $\mathrm{Ca}^{2+}$ pumps and the role of the Golgi apparatus as a $\mathrm{Ca}^{2+}$ store. Pflugers Arch 446: 148-153. doi:10.1007/s00424003-1011-5

Yabe D, Taniwaki M, Nakamura T, Kanazawa N, Tashiro K, Honjo T. 1998. Human calumenin gene (CALU): cDNA isolation and chromosomal mapping to $7 \mathrm{q} 32$. Genomics 49: 331-333. doi:10.1006/geno.1998.5245

Yoshida M, Minamisawa S, Shimura M, Komazaki S, Kume H, Zhang M, Matsumura K, Nishi M, Saito M, Saeki Y, et al. 2005. Impaired $\mathrm{Ca}^{2+}$ store functions in skeletal and cardiac muscle cells from sarcalumenin-deficient mice. $J$ Biol Chem 280: 3500-3506. doi:10.1074/jbc.M406618200 
Yu R, Hinkle PM. 2000. Rapid turnover of calcium in the endoplasmic reticulum during signaling. Studies with cameleon calcium indicators. J Biol Chem 275: 2364823653. doi:10.1074/jbc.M002684200

Zhang SL, Yu Y, Roos J, Kozak JA, Deerinck TJ, Ellisman MH, Stauderman KA, Cahalan MD. 2005. STIM1 is a $\mathrm{Ca}^{2+}$ sensor that activates CRAC channels and migrates from the $\mathrm{Ca}^{2+}$ store to the plasma membrane. Nature 437: 902-905. doi:10.1038/nature04147

Zhang SJ, Zou M, Lu L, Lau D, Ditzel DA, Delucinge-Vivier C, Aso Y, Descombes P, Bading H. 2009. Nuclear calcium signaling controls expression of a large gene pool: Identification of a gene program for acquired neuroprotection induced by synaptic activity. PLoS Genet 5: e1000604 doi:10.1371/journal.pgen.1000604

Zhao X, Yoshida M, Brotto L, Takeshima H, Weisleder N, Hirata Y, Nosek TM, Ma J, Brotto M. 2005. Enhanced resistance to fatigue and altered calcium handling properties of sarcalumenin knockout mice. Physiol Genomics 23: 72-78. doi:10.1152/physiolgenomics.00 020.2005

Zheng L, Stathopulos PB, Li GY, Ikura M. 2008. Biophysical characterization of the EF-hand and SAM domain containing $\mathrm{Ca}^{2+}$ sensory region of STIM1 and STIM2. Biochem Biophys Res Commun 369: 240-246. doi:10.1016/j bbrc.2007.12.129 


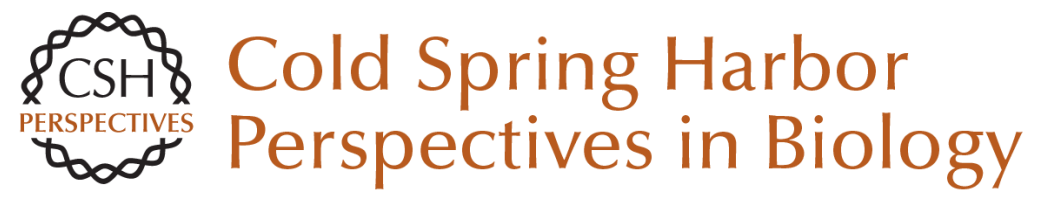

\section{Organellar Calcium Handling in the Cellular Reticular Network}

Wen-An Wang, Luis B. Agellon and Marek Michalak

Cold Spring Harb Perspect Biol 2019; doi: 10.1101/cshperspect.a038265 originally published online July 29, 2019

\section{Subject Collection Calcium Signaling}

The Endoplasmic Reticulum-Plasma Membrane Junction: A Hub for Agonist Regulation of $\mathrm{Ca}^{2+}$ Entry

Hwei Ling Ong and Indu Suresh Ambudkar

Calcium-Handling Defects and Neurodegenerative Disease

Sean Schrank, Nikki Barrington and Grace E. Stutzmann

Lysosomal $\mathrm{Ca}^{2+}$ Homeostasis and Signaling in Health and Disease

Emyr Lloyd-Evans and Helen Waller-Evans

\section{$\mathrm{Ca}^{2+}$ Signaling in Exocrine Cells}

Malini Ahuja, Woo Young Chung, Wei-Yin Lin, et al.

Functional Consequences of Calcium-Dependent Synapse-to-Nucleus Communication: Focus on Transcription-Dependent Metabolic Plasticity Anna M. Hagenston, Hilmar Bading and Carlos Bas-Orth

Identifying New Substrates and Functions for an Old Enzyme: Calcineurin Jagoree Roy and Martha S. Cyert

Fundamentals of Cellular Calcium Signaling: A Primer

Martin D. Bootman and Geert Bultynck
Primary Active $\mathrm{Ca}^{2+}$ Transport Systems in Health and Disease Jialin Chen, Aljona Sitsel, Veronick Benoy, et al.

Signaling through $\mathrm{Ca}^{2+}$ Microdomains from Store-Operated CRAC Channels Pradeep Barak and Anant B. Parekh

Structural Insights into the Regulation of $\mathrm{Ca}^{2+}$ /Calmodulin-Dependent Protein Kinase II (CaMKII) Moitrayee Bhattacharyya, Deepti Karandur and John Kuriyan

Store-Operated Calcium Channels: From Function to Structure and Back Again Richard S. Lewis

Bcl-2-Protein Family as Modulators of $\mathrm{IP}_{3}$

Receptors and Other Organellar $\mathrm{Ca} 2+$ Channels Hristina Ivanova, Tim Vervliet, Giovanni Monaco, et al.

Calcium Signaling in Cardiomyocyte Function Guillaume Gilbert, Kateryna Demydenko, Eef Dries, et al.

Cytosolic $\mathrm{Ca}^{2+}$ Buffers Are Inherently $\mathrm{Ca}^{2+}$ Signal Modulators Beat Schwaller

For additional articles in this collection, see http://cshperspectives.cshlp.org/cgi/collection/

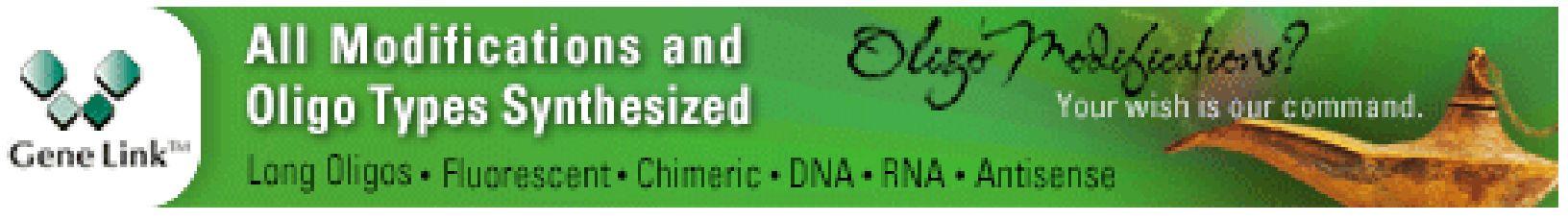


Role of Two-Pore Channels in Embryonic Development and Cellular Differentiation Sarah E. Webb, Jeffrey J. Kelu and Andrew L. Miller

\section{Organellar Calcium Handling in the Cellular \\ Reticular Network}

Wen-An Wang, Luis B. Agellon and Marek Michalak

For additional articles in this collection, see http://cshperspectives.cshlp.org/cgi/collection/

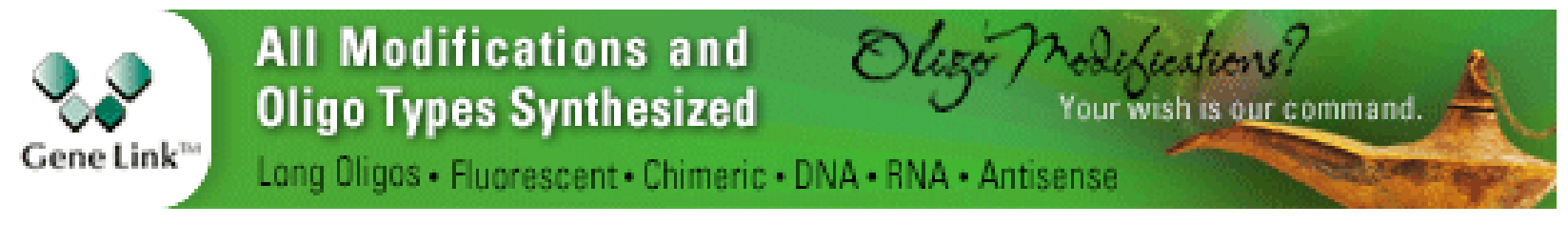

Copyright @ 2019 Cold Spring Harbor Laboratory Press; all rights reserved 